\title{
Cell types, morphology and evolution of animal excretory organs
}

Andrikou, Carmen; Gąsiorowski, Ludwik; Hejnol, Andreas

University of Bergen, Department of Biological Sciences, Thormøhlensgate 55, 5006

Bergen, Norway

\begin{abstract}
Excretion and osmoregulation are fundamental processes of the organism, as they prevent the accumulation of toxic waste products in the body and control the osmotic differences between the cells and the environment. In most of the animals these phenomena are taking place through specialized organs, namely excretory organs, composed of diverse cell types that are performing tasks such as secretion and ultrafiltration. Although the morphology and embryology of excretory organs can differ dramatically, the common spatial arrangement of structural proteins and transporters as well as the similar transcriptional developmental programs underlying their formation suggests the homology of their cell types. In this chapter we discuss the current understanding of the evolution of excretory organs from a comparative morphological, developmental and functional perspective, flanked by an additional, cell-type perspective. We argue that a putative homologization of certain excretory cell types does not necessarily reflect the homology of the resulting organs, and that integrating all different levels of comparison is crucial for addressing evolutionary questions.
\end{abstract}

\section{Introduction}

All animals (Metazoa) need to excrete metabolic waste products from their body (Larsen et al., 2014; Schmidt-Nielsen, 1997; Schmidt-Rhaesa, 2007). On a cellular level, this process is taking place via transmembrane proteins that are specialized for transporting these products in the context of ion gradients (Ichimura and Sakai, 2017; Larsen et al., 2014; O'Donnell, 2010; Schmidt-Nielsen, 1997; Weihrauch and O'Donnell, 2017). It is widely believed that non-bilaterian animals excrete via passive diffusion through their integument, although this hypothesis has been challenged by a recent work on cnidarian and xenacoelomorph species (Andrikou et al., 2019). However, most bilaterians possess specialized excretory organs that remove metabolites more efficiently (Fig. 1). These organs are diverse, and their evolutionary relationship has puzzled many zoologists since their discovery (Bartolomaeus and Ax, 1992; Bartolomaeus and Quast, 2005; Goodrich, 1945; Ichimura and Sakai, 2017; Koch et al., 2014; Ruppert, 1994; Ruppert and Smith, 1988; Schmidt-Rhaesa, 2007). Nephridia, kidneys, 
Malpighian tubules etc. are composed out of different cell types that can be discriminated by their morphology and function (e.g. (Goodrich, 1945; Ruppert and Smith, 1988; SchmidtRhaesa, 2007)). The embryology of these organs is also intriguing, because it varies between species and also involves, in some cases (e.g. metanephridia), an interaction between cells of different germ layers, such as mesoderm and ectoderm (Bartolomaeus, 1989; Goodrich, 1945; Lüter, 1995; Ruppert, 1994; Schmidt-Rhaesa, 2007). When and how many times these specialized organs evolved remains unclear. In the context of the placement of the Xenacoelomorpha as sister group to all remaining Bilateria, a new taxon name for Protostomia + Deuterostomia has been introduced, namely Nephrozoa (Jondelius et al., 2002). This refers to the presence of excretory organs (i.e. nephridia) in the last common ancestor of this clade that would also be an apomorphy of Nephrozoa (Fig. 1). Here we aim to describe the astonishing variability seen in excretory organs from a cell-type perspective, for which the diversity in morphology, development and functional composition can be particularly challenging. We interpret this diversity from an evolutionary perspective and discuss problems in homologization on different levels. 


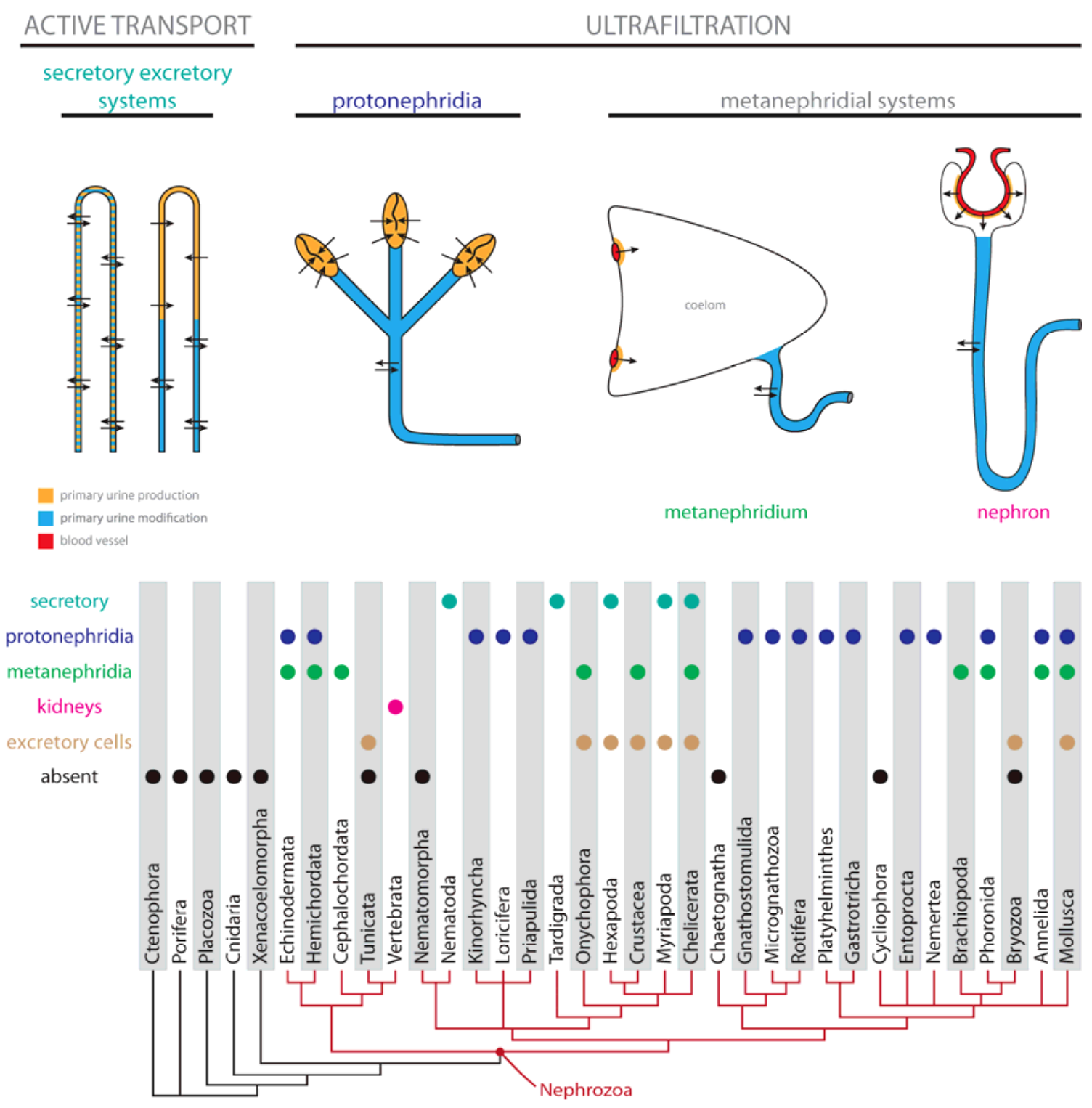

Figure 1. Excretory systems distribution across the animal tree. Schematic drawings and typology of basic types of excretory organs with color coded sites of primary urine production and modification (see text for details). Distribution of different types of excretory organs in nephrozoan clades.

\section{Diversity of cell types in excretory organs: a morphological perspective}

Excretion in most of the Nephrozoa is a two-stage process (Ichimura and Sakai, 2017; Ruppert, 1994; Ruppert and Smith, 1988; Schmidt-Nielsen, 1997; Schmidt-Rhaesa, 2007). Initially the body fluid (e.g. blood, haemolymph or interstitial fluid) is roughly filtered from large proteins and cells to produce the so-called primary urine (Ichimura and Sakai, 2017; Schmidt-Rhaesa, 2007). This initial product becomes later secondarily modified (e.g. the ion concentration or water volume can be specifically changed), resulting in the finite secondary urine, which is eventually expelled from the body (Schmidt-Nielsen, 1997; Schmidt-Rhaesa, 2007). As there are many ways in which those two processes can be 
performed, the excretory organs vary greatly regarding their morphology and physiology and, as a consequence, in the diversity and spatial arrangement of the particular cell types, which built them.

Traditionally, zoologists group excretory organs based on their physiological and structural properties into categories, which reflect rather functional than evolutionary similarities (Fig. 1; (Bartolomaeus and Ax, 1992; Ichimura and Sakai, 2017; Ruppert and Smith, 1988; Schmidt-Rhaesa, 2007)). The most basic division relates to the mechanism of primary urine production - in the secretory excretory organs the active intracellular transport is used for that purpose, whereas in the ultrafiltration-based systems the primary urine is filtered through semipermeable extracellular membrane - a filter composed of either extracellular matrix (ECM) or slit diaphragm or both (Fig. 1; (Ichimura and Sakai, 2017; Schmidt-Nielsen, 1997; Schmidt-Rhaesa, 2007)). The latter category includes protonephridia, where ultrafiltration is driven by the ciliary action, and the metanephridial system in which blood pressure is used to produce primary urine (Bartolomaeus and Ax, 1992; Ichimura and Sakai, 2017; Ruppert, 1994; Ruppert and Smith, 1988; Schmidt-Rhaesa, 2007). Among metanephridial systems it is possible to distinguish between vertebrate kidneys, in which ultrafiltration and secondary urine modification occurs in the single structural unit (i.e. nephron with glomerulus) and invertebrate metanephridial systems in which ultrafiltration and secondary urine modification are spatially separated, the former happening in the coelom lining and the latter in the metanephridium itself (Ichimura and Sakai, 2017; Schmidt-Nielsen, 1997; Schmidt-Rhaesa, 2007).

\section{Secretory excretory organs (Malpighian tubules and others)}

Among the best-known examples of the secretory excretory organs are the Malpighian tubules, the prevalent excretory organs in many Panarthropoda taxa. Although Malpighian tubules are found in representatives of Eutardigrada, Chelicerata, Myriapoda and Hexapoda (Fig. 1), it remains unknown if they are all homologous to each other or if they rather evolved independently in particular lineages (Bitsch and Bitsch, 2004; Greven, 1982; Paulus, 2000). Those organs are tubular invaginations of the gut (originating close to the midgut-hindgut transition), which penetrate the haemocoel; distally they are blindly ended and proximally they open to the gut lumen (Berridge and Oschman, 1969; Eichelberg and Wessing, 1975; Nocelli et al., 2016; Schmidt-Nielsen, 1997; Schmidt-Rhaesa, 2007). Malpighian tubules are surrounded by a basal lamina, which serves as a barrier for cells and large proteins. Both their external and internal surface is greatly increased by respectively basal infoldings and microvillar structures, which enhance cellular uptake and secretion (Berridge and Oschman, 1969; Maddrell, 1980). In insects the organs are additionally 
equipped with contractile muscle fibers and tracheae (e.g. (Bradley, 1983; Garayoa et al., 1992; Li et al., 2015; Taylor, 1971b; Wall et al., 1975).

Often there are two basic cell types in Malpighian tubules - e.g. many insects possess 1) primary cells (known as well as type I cells), which produce primary urine and are characterized from numerous mitochondria-rich, external, basal infoldings and internal microvilli and 2) less abundant secondary or stellate cells (known as well as type II cells) with less developed microvilli, which are likely involved in the secondary urine modification (e.g. (Berridge and Oschman, 1969; Dow and Davies, 2001; Kapoor, 1994; Li et al., 2015; Nocelli et al., 2016; Pal and Kumar, 2012; Taylor, 1971a, b; Wall et al., 1975). In some animals Malpighian tubules seem to include additional cell types - e.g. in tardigrades "supportive" cells are present next to primary and secondary cells (Møbjerg and Dahl, 1996; Węglarska, 1980).

It is evident that not only cell type diversity, but also their spatial distribution along the organ is crucial for the evolution of Malpighian tubules. The two basic cell types - the primary urine producing and the secondarily modifying ones - can be a) uniformly distributed along the tubule as it is case in many insects (Berridge and Oschman, 1969; Dow and Davies, 2001; Kapoor, 1994; Nocelli et al., 2016; Pal and Kumar, 2012; Taylor, 1971a, b; Wall et al., 1975), or b) restricted to the respectively proximal and distal portion of the tubule, resulting in a clear division of the organ into distinct parts responsible for urine production and secondary modification, as in e.g. tardigrades (Møbjerg and Dahl, 1996; Schill, 2019; Węglarska, 1980), millipedes (Johnson and Riegel, 1977) or some insects (Arab and Caetano, 2002; Bradley, 1983; Green, 1979, 1980; Li et al., 2015; Nicholls, 1983; Nocelli et al., 2016). The subdivision of Malpighian tubules into distinct regions with different cell types has been also shown in spiders, however the function of the cells in each section is not clear (Hazelton et al., 2002; Seitz, 1987).

Secretory excretory organs are also found among nematodes in which the two different basic types can be recognized (reviewed in (Chitwood and Chitwood, 1950)). Some of the free-living, mostly marine forms (once united into the group Aphasmidia=Adenophorea) have a single large glandular cell used for excretion, the socalled ventral gland, which opens to the exterior by the single pore. Members of the clade Phasmidia (=Secernentea), which include most of the parasitic forms, as well as a model species Caenorhabditis elegans, possess a specialized excretory organ, which consists of several cells, each with different ultrastructure and function (e.g. (McLaren, 1974; Nelson et al., 1983; Waddell, 1968). The exact number and types of cells might vary but generally the organ always represents some modification of the so-called $\mathrm{H}$-system (Chitwood and Chitwood, 1950). There is an unpaired sinus cell which opens to the exterior by a ventromedian terminal duct lined with cuticle. From the sinus two pairs of longitudinal, lateral 
canals extend in the lateral hypodermal cords to the anterior and posterior portion of the animal. Each canal is built by a single cell with intracellular lumen (sometimes canals are projections of the sinus cell, e.g. (Nelson et al., 1983)), which can show spatial differentiation into smooth and microvillar portions (McLaren, 1974; Waddell, 1968). Additional glandular, sphincter or lip cells can be associated with the terminal duct (Chitwood and Chitwood, 1950; McLaren, 1974; Nelson et al., 1983; Waddell, 1968). The molecular phylogeny of nematodes shows that species with $\mathrm{H}$-systems (or its modification) represents a monophyletic group whereas species with single cell excretory gland are forming a basal grade (Holterman et al., 2006; Smythe et al., 2019), hence the latter should be considered as plesiomorphic nematode arrangement, whereas the former represent synapomorphy of Secernentea. Both systems are nematode specific and represent derived excretory organs not easily comparable with any structures found in remaining Nephrozoa.

Interestingly, the putative unicellular secretory excretory organs were also described in the acoel Paratomella rubra (Ehlers, 1992), representing likely an evolutionary gain of excretory organs independent from nephrozoan lineage (Andrikou et al., 2019). The socalled dermonephridia are specialized epidermal cells, randomly distributed in the epidermis, which lack cilia but possess modified long microvilli on their apical surface and intracellular lacunar system of tubules and vacuoles, which communicate with the exterior. Taking into account that dermonephridia are known only from a single acoel species they probably represent a recent evolutionary novelty.

\section{Protonephridia}

Protonephridia use ultrafiltration through extracellular filters driven by ciliary action (Bartolomaeus and Ax, 1992; Ichimura and Sakai, 2017; Ruppert, 1994; Ruppert and Smith, 1988; Schmidt-Nielsen, 1997; Schmidt-Rhaesa, 2007) (Figs. 1). Some of the simplest protonephridia among entire animal kingdom are found in Gnathostomulida (Fig. 2; (Lammert, 1985)), a group of microscopic marine worms closely related with rotifers. Each of the gnathostomulid protonephridium consists of only three cells and can be used as an example of the minimal and most basic cellular architecture required for this type of organs (Fig. 2; (Lammert, 1985)). The most proximal (or terminal) cell has single cilium surrounded by the cytoplasmic portion (so-called filtering area) traversed by irregular clefts closed with a filtering membrane (i.e. slit diaphragm). The tubular filtering area tightly adjoins to the second cell of the system - the canal cell - that harbors the intracellular canal into which the cilium of the terminal cell protrudes. The canal cell is non-ciliated and has a complicated lacunar system and microvilli facing the canal lumen, which both greatly increase the cellular surface. Laterally, the canal cell adjoins the nephroporus cell, which is a modified epidermal cell, 
through which a canal of the protonephridium communicates with the exterior. The terminal cell provides the filter as well as the negative pressure necessary for the ultrafiltration and is therefore the site of primary urine production. The canal cell, on the other hand, is responsible for the secondary modification of the urine. Importantly, both components of the organ show ultrastructural characteristics of epidermal cells, indicating that the entire organ has an ectodermal origin (Lammert, 1985).

There are two ways in which this extremely simple system can be complicated in other protonephridia-bearing animals. First of all, particular cells can be multiplied resulting in e.g. many terminal cells opening to the single canal cell (e.g. in some gastrotrichs, Fig. 2, (Kieneke et al., 2008; Kieneke and Hochberg, 2012; Teuchert, 1973) or some kinorhynchs, Fig. 2, (Kristensen and Hay-Schmidt, 1989)), one terminal cell can open to the canal built of many similar canal cells (e.g. in annelid Apodotrocha, Fig. 2; (Westheide, 1985)) or both elements can be multiplied (e.g. in some Kinorhyncha and Loricifera; (Neuhaus, 1988; Neuhaus and Kristensen, 2007) or in Nemertea (Bartolomaeus, 1985)). When terminal cells are multiplied, each of them might form a separate filtering unit (Bartolomaeus, 1985; Teuchert, 1973) or they can be merged together, with the filtering area formed by two or more adjacent cells (Kieneke et al., 2008; Kieneke and Hochberg, 2012; Kristensen and HaySchmidt, 1989; Neuhaus, 1988; Neuhaus and Kristensen, 2007).

Apart from cell multiplication, additional cell types might be present in the protonephridial organs of some animals, increasing spatial diversification and functional specification of the nephridium. For instance, in some platyhelminths the multicellular canal is divided into the proximal ciliated zone to which the terminal cells open and a distal zone, built exclusively by cells with extensive microvilli on the luminal surface (Rohde and Watson, 1993; Scimone et al., 2011; Vu et al., 2015). Additionally, it has been demonstrated, that in planarians those two parts express different sets of solute carrier transporters and apparently have different roles in the secondary urine modification ( $\mathrm{Vu}$ et al., 2015). In microscopic rotifers the canal is built of two or three distinct cell types (Ahlrichs, 1993a; Ahlrichs, 1993b; Warner, 1969) and additionally in monogononts it opens to the muscular bladder, which collects urine from paired protonephridial systems (Ahlrichs, 1993b; Warner, 1969). The cellular complexity of the rotifer excretory system is further increased due to the fact that some of its parts are of syncytial nature. 


\section{Diversity of protonephridia}

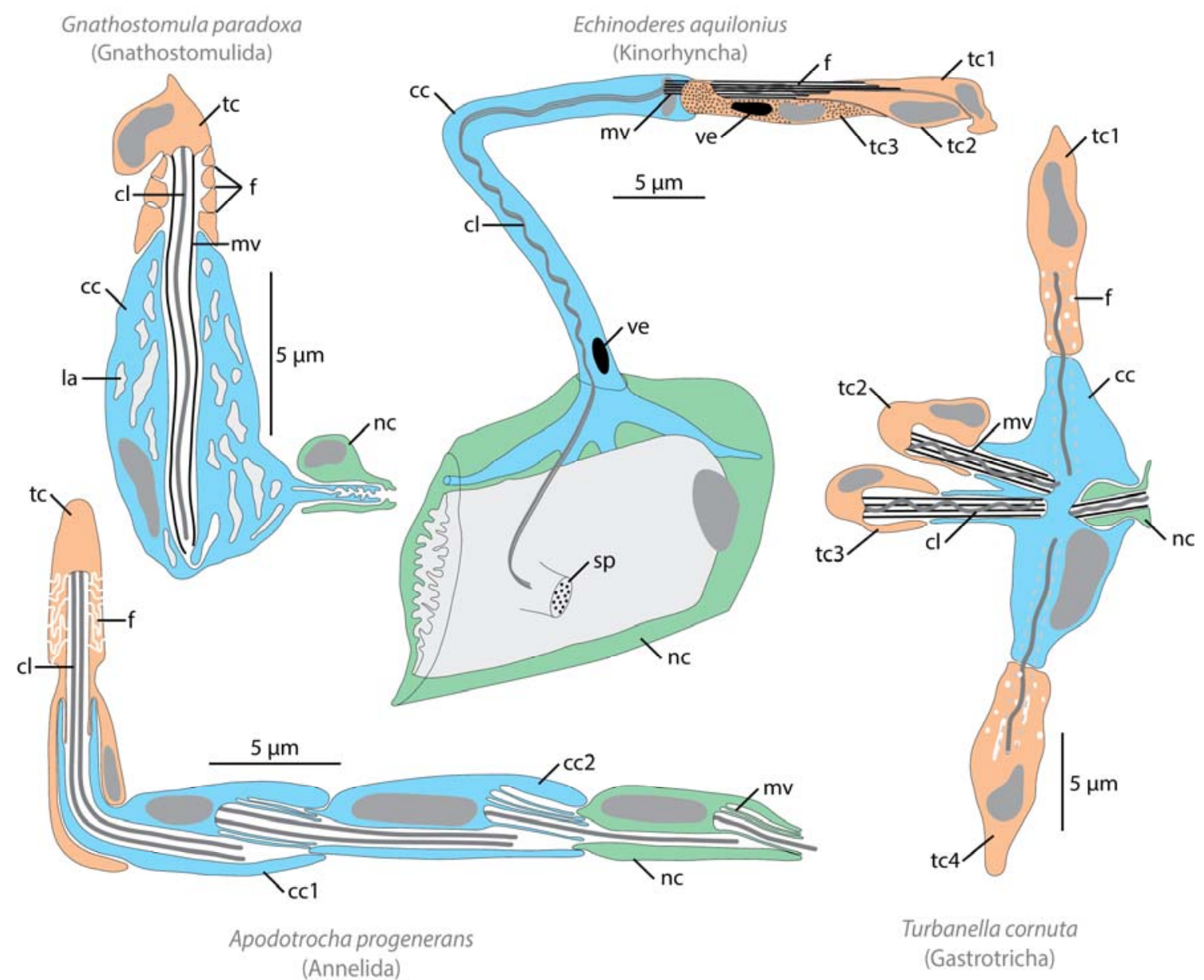

Figure 2. Morphological diversity of protonephridia. Schematic reconstruction of various protonephridial systems as inferred from TEM studies, based on (Kristensen and Hay-Schmidt, 1989; Lammert, 1985; Teuchert, 1973; Westheide, 1985). In all drawings primary urine filtering cells (terminal cells) are in orange, primary urine modifying cells (canal cells) in blue, nephroporus cells in green, cell nuclei in dark grey and intracellular cavities in light gray. Abbreviations: cc canal cell, cl cilium, $\mathbf{f}$ protonephridial filter, la lacunar system, mv microvilli, nc nephroporus cell, sp sieve plate (cuticular opening for protonephridium), tc terminal cell, ve vesicle. Number after abbreviation indicate multiplication of particular cell type.

Protonephridia are present in many invertebrate taxa (sometimes only in larvae e.g. in phoronids, some molluscs and annelids; see (Baeumler et al., 2011; Bartolomaeus, 1989; Bartolomaeus and Quast, 2005; Goodrich, 1945; Hay-Schmidt, 1987; Koch et al., 2014; Ruthensteiner et al., 2001; Temereva and Malakhov, 2006; Todt and Wanninger, 2010) and even though they are often considered plesiomorphic (e.g. (Bartolomaeus and Ax, 1992) they show remarkable diversity and evolutionary variation related with the fact that their particular elements can be easily organized in various ways (Ichimura and Sakai, 2017). For example, the filter might be built by a single cell with irregular openings, a single cell with slits, two adjacent terminal cells with interdigitating processes or a terminal cell and a canal cell forming a common weir (Kieneke et al., 2008). Additionally, it might stand with or without 
diaphragm, with or without supporting microvilli, microvilli might be differentiated or uniform etc.. The terminal cell might be monociliated (also called solenocyte), multiciliated with independent cilia (then known as cyrtocyte) or multiciliated with all the cilia forming a single structure, the so-called flame as in e.g. rotifers or some platyhelminthes (Riemann and Ahlrichs, 2010; Rohde, 1991). The canal might be intracellular or multicellular, with or without cilia, spatially diversified or uniform etc. However, despite all their diversity, protonephridia are always straightforwardly comparable to each other (Bartolomaeus and Ax, 1992) and the primary homology statements regarding their particular portions can be readily made. The distribution of the protonephridia-bearing animals on the phylogenetic tree (Fig. 1), suggests that those organs evolved either twice, once in Scalidophora and once in Spiralia, or are homologous between those two groups. This makes protonephridia an excellent model for studying the evolution of complexity and functionality of the excretory organs over long evolutionary time, combining morphological, cellular and molecular levels.

\section{Metanephridial systems}

The typical metanephridia (Figs. 1, 3) are present in some annelids (e.g. (Bartolomaeus and Quast, 2005; Goodrich, 1945), in brachiopods (Kuzmina and Malakhov, 2015; Lüter, 1995), adult phoronids (Bartolomaeus, 1989; Storch and Herrmann, 1978; Temereva and Malakhov, 2006), cephalochordates (Ichimura and Sakai, 2017; Moller and Ellis, 1974; Ruppert, 1994) and adult hemichordates (Balser and Ruppert, 1990; Dilly et al., 1986; Mayer and Bartolomaeus, 2003). Furthermore, the onychophoran nephridia (Mayer, 2006), coxal glands of Chelicerata (Briggs and Moss, 1997; Koch et al., 2014), antennal gland of Crustacea (Bartolomaeus et al., 2009; Khodabandeh et al., 2005), molluscan heartkidneys (Baeumler et al., 2011; Bartolomaeus, 1997) and the axial organ of echinoderms (Balser and Ruppert, 1993; Ezhova et al., 2013, 2014; Welsch and Rehkamper, 1987; Ziegler et al., 2009) can be also considered as metanephridial excretory systems, at least from the functional point of view. The ultrafiltration occurs in invertebrate metanephridial systems (Fig. 3) between blood vessels (or their functional equivalents, e.g. haemocoelic sinus) and the coelomic lining where specialized cells - podocytes (Fig. 3) - are present (Bartolomaeus and Ax, 1992; Ichimura and Sakai, 2017; Ruppert, 1994; Ruppert and Smith, 1988; Schmidt-Rhaesa, 2007). The primary urine is therefore synonymous with the coelomic fluid in those animals (Bartolomaeus and Ax, 1992; Ruppert, 1994; Schmidt-Rhaesa, 2007). The fluid leaves the coelom through the spatially independent structure, a metanephridium (Fig. 3), which often consists of the proximal dilated portion (i.e. ciliated funnel) and the distal region (i.e. nephroduct), which might be further subdivided into regions with differing functions and cell type composition (Goodrich, 1945; Schmidt-Rhaesa, 2007). Therefore, 
compared to protonephridia, many different cell types build metanephridial systems and their exact number and qualitative composition varies from taxon to taxon, showing diverse ultrastructural, developmental and functional characteristics. In some animals - e.g. phoronids or some annelids - the metanephridia are ontogenetically predated by protonephridia (Bartolomaeus, 1989; Bartolomaeus and Quast, 2005; Goodrich, 1945; Koch et al., 2014; Temereva and Malakhov, 2006). In such instances the terminal cells of the protonephridium degenerate during metamorphosis, and the adult metanephridium develops from the larval protonephridial canal, whereas the podocytes develop de novo from the myoepitheliocytes (Bartolomaeus, 1989; Bartolomaeus and Quast, 2005; Bartolomaeus et al., 2009; Storch and Herrmann, 1978; Temereva and Malakhov, 2006). The term nephromixium is sometimes used to refer to such definite organ of dual origin (Goodrich, 1945; Temereva and Malakhov, 2006). On the other hand in Panarthropoda taxa, the podocyte-bearing cavity, called sacculus, does not seem to be formed by the coelom but rather by dilatation of the blind end of the developing nephroduct (summarized and discussed in (Koch et al., 2014)). Nephridia in Arthropoda are further distinguishable from those found in other animals (including onychophorans) by lacking any ciliation (Mayer, 2006).

In the vertebrate kidney, the excretion is carried out in the structural unit called nephron (Fig. 1; e.g. (Gérard, 1936; Ichimura and Sakai, 2017; Ruppert, 1994; Vize et al., 1997)), which due to its importance in human physiology is very well studied on morphological, physiological, developmental and molecular levels (e.g. (Bates, 2016; Desgrange and Cereghini, 2015; Dressler, 2006; Lindström et al., 2018; Little et al., 2010; McMahon, 2016; Quaggin and Kreidberg, 2008)). There are three types of nephrons found among vertebrates: the closed glomerular (present in e.g. mammalian kidney), opened glomerular (e.g. in salamanders) and aglomerular ones (found exclusively in some teleosts) (Gérard, 1936; Schmidt-Nielsen, 1997). The first two are relatively similar: both have a glomerular portion (also known as Bowman capsule), where filtering cells - podocytes tightly surround capillaries lined with the extremely thin-walled fenestrated endotheliocytes (Bates, 2016; Ichimura and Sakai, 2017; Koriyama et al., 1992; Schmidt-Nielsen, 1997; Wolff and Merker, 1966). The primary ultrafiltrate passes through the endothelium-ECM-podocytes barrier and is subsequently accumulated inside the capsule, from where it is drained by the proximal nephron tubule. Aside from the podocytes and endotheliocytes two additional cell types of predominantly supportive function are found in the glomerulus - mesangial cells, which support capillaries (but also contribute to filtration of some molecules directly from the bloodstream) and parietal cells, which exclusively build the external wall of Bowman capsule (Dressler, 2006; Ichimura and Sakai, 2017; Quaggin and Kreidberg, 2008; Vize et al., 1997). The nephron tubule leads from the glomerulus to the collective duct, which eventually opens 
to the urinary bladder. The tubule is differentiated into proximal, intermediate and distal regions, which differs in function and consequently in cell types of which they are composed (Bates, 2016; Desgrange and Cereghini, 2015; Lindström et al., 2018; Little et al., 2010; Schmidt-Nielsen, 1997). The main difference between closed and opened glomerular nephrons is that in the latter the additional ciliated canal (composed of yet another cell type) connects its proximal tubule with the peritoneal cavity (Gérard, 1936). The aglomerular nephron, on the other hand, is found only in some, mostly marine, teleosts (Gérard, 1936; Ichimura and Sakai, 2017; Schmidt-Nielsen, 1997). It lacks glomerular capsule and in fact utilize only active transport through the cells for primary urine production (Bulger, 1965; Dobbs and Devries, 1975; Schmidt-Nielsen, 1997), which makes it actually an example of a secretory excretory organ. It is, however, homologous to the glomerular nephron and, in some species, it ontogenetically develops from the glomerular condition (Gérard, 1936).

Depending on the arrangement of nephrons in the organ it is possible to distinguish between a mesonephros and a metanephros (Fig. 3; (Bates, 2016; Ichimura and Sakai, 2017; Vize et al., 1997)). In amniotes, they form an ontogenetic series with the metanephros being a definite excretory organ and the mesonephros is found only in the embryonic or larval stages (Bates, 2016; Vize et al., 1997). The earliest developmental stage of the vertebrate kidney - pronephros - does not have separate nephrons: the glomerulus and nephric duct are spatially separated, whereas the primary urine is accumulated inside coelom (Fig. 3; e.g. (Møbjerg et al., 2000; Vize et al., 1997); from the functional perspective it can be therefore categorized as the proper metanephridial system (Ichimura and Sakai, 2017). 

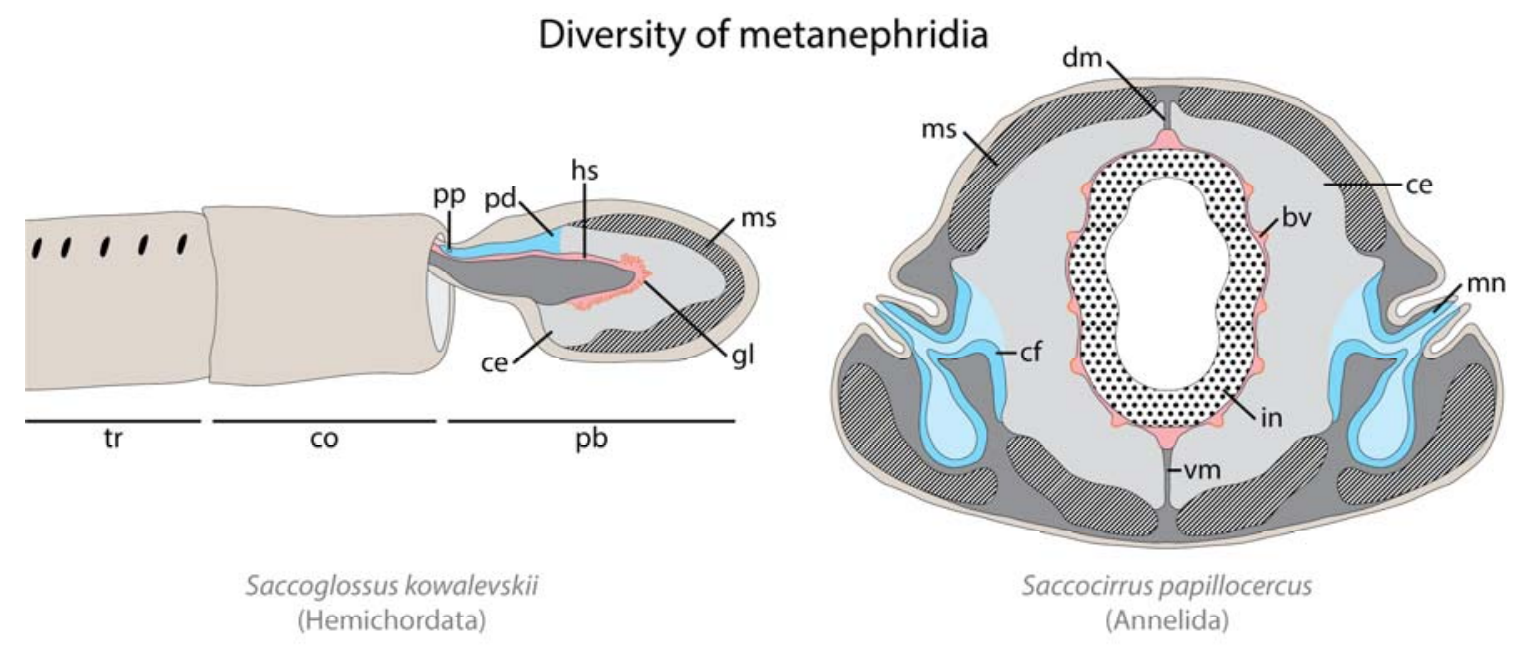

Podocytes in metanephridia

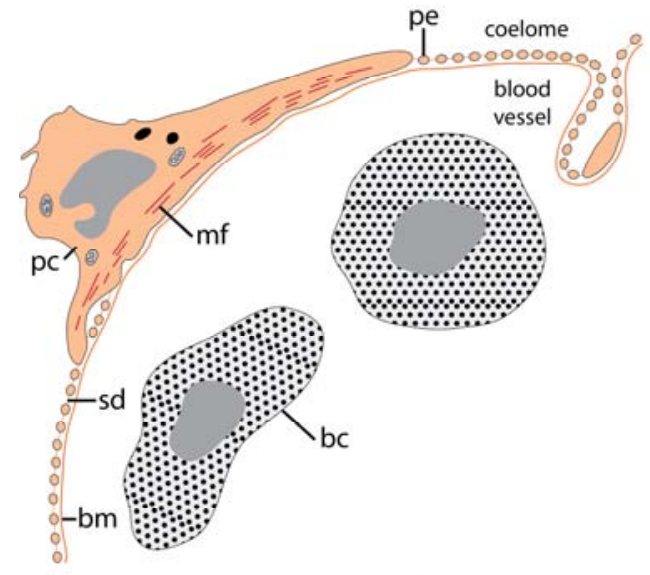

Phoronis muelleri (Phoronida)

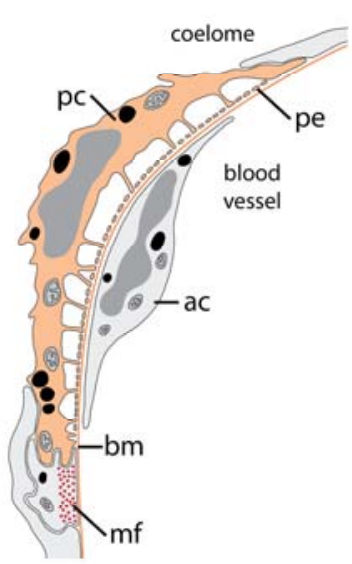

Tubifex tubifex (Annelida)

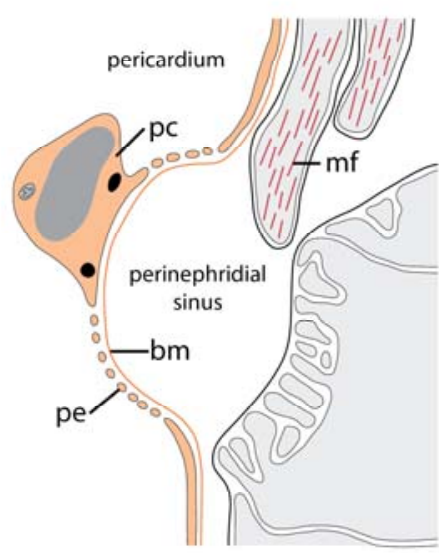

Philinoglossa helgolandica (Mollusca)

\section{Development of vertebrate kidney}

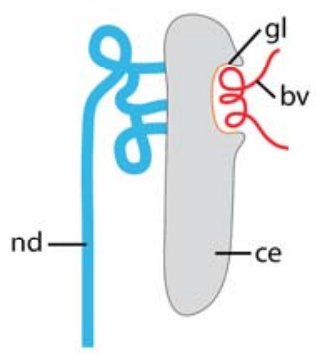

pronephros

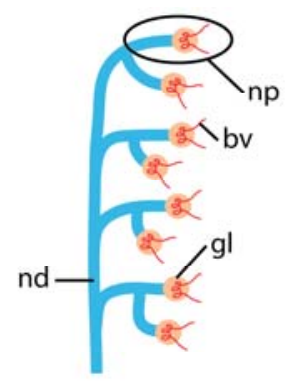

mesonephros

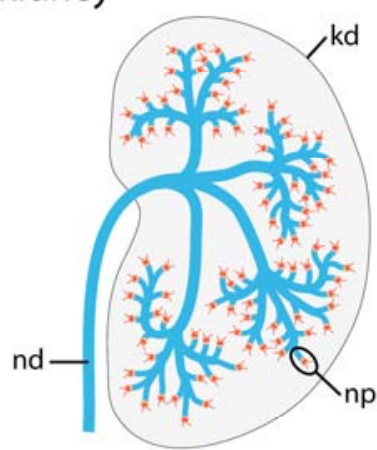

metanephros

Figure 3. Morphological diversity of metanephridial systems. Schematic drawings of metanephridial systems in hemichordate (Iongitudinal section) and annelid (cross section), based on (Balser and Ruppert, 1990) and (Goodrich, 1945). Schematic drawings of podocytes present in various invertebrates reconstructed from TEM sectioning, based on (Bartolomaeus, 1997; Peters, 1977; Storch and Herrmann, 1978). Schematic organization of three developmental stages of vertebrate excretory organs adapted from (Vize et al., 1997). In all drawings blood vessels are in red, sites of primary urine filtration in orange and 
sites of primary urine modification in blue. Abbreviations: ac amebocyte, bc blood cell, bm basal membrane, bv blood vessel, ce coelom, cf ciliated funnel, co collar region, dm dorsal mesentery, gl glomerulus, hs heart sinus, in intestine, kd kidney, mf myofibrils, $\mathbf{m n}$ metanephridium, ms musculature, $\mathbf{n d}$ nephric duct, $\mathbf{n p}$ nephron, pb proboscis, pc podocyte, pd protocoel duct, pe pedicle, pp proboscis pore, sd slit diaphragm, tr trunk region, vm ventral mesentery.

The most distinctive cell type that seems to be shared by all metanephridial systems (including kidneys) is a podocyte (Ichimura and Sakai, 2017; Ruppert, 1994). Cells of this type are divided into the cell body and pedicles - long projections, which interdigitate with each other (Fig. 3). On the junctions of the pedicles the proteins anchored in the podocyte cell membrane might form the filtering membrane - a slit diaphragm (Fig. 3; e.g. (Gerke et al., 2003; Ichimura and Sakai, 2017; Quaggin and Kreidberg, 2008; Storch and Herrmann, 1978; Tryggvason and Wartiovaara, 2001). Interestingly, a filtering region of terminal protonephridial cells of planarians shares some ultrastructural and molecular similarities with the filtering portion of the podocyte (Ichimura and Sakai, 2017; Vu et al., 2015). Taking into account that metanephridia probably evolved independently at least few times in the animal kingdom (Fig. 1; (Bartolomaeus, 1997; Bartolomaeus and Ax, 1992; Koch et al., 2014)), the podocytes of various animal groups represent analogous cell types (Bartolomaeus and $A x$, 1992), which likely evolved by independent modification of the same ancestral filtering mechanism (e.g. from terminal cells of protonephridia) (Ruppert, 1994).

\section{Excretory cells}

In addition to multicellular excretory organs (and sometimes instead of them) some animals possess specialized cells, which serve for excretory purposes (Haszprunar, 1996; Ruppert, 1994). Instead of expelling toxic waste products from the animal body, these cells accumulate the excreted substances inside their cytoplasm. Such accumulative excretory cells have been reported in a wide range of animals (Fig. 1) and although they are generally referred as nephrocytes, their ultrastructure and function differ from taxon to taxon.

The most studied excretory cells among nephrocytes are cells present in arthropods and onychophorans (Coons et al., 1990; Crossley, 1972; El-Shoura, 1989; Hessler and Elofsson, 1995; Seifert and Rosenberg, 1977; Shatrov, 1998; Vandenbulcke et al., 1998; Weavers et al., 2009). These cells, located inside haemolymph-filled cavities, are surrounded by ECM and resemble isolated podocytes with diaphragm-like structure. The waste products and other toxic compounds are filtered through the ECM and diaphragm and accumulate inside the nephrocytes (Vandenbulcke et al., 1998; Weavers et al., 2009). Insects have two sets of nephrocytes with similar ultrastructural properties - garland cells around esophagus and pericardial cells located on the heart walls (Crossley, 1972; Weavers et al., 2009). Cells with similar ultrastructure and function have been also reported in mollusks, where they are 
called rhogocytes (Haszprunar, 1996; Rivest, 1992; Ruthensteiner et al., 2001). It has been proposed, based on molecular similarities (homology of the proteins forming diaphragm) and intermediate morphological forms, that both arthropod nephrocytes and molluscan rhogocytes are actually homologues of the filtering nephridial cells, which became spatially separated from an ancestral excretory organ (Haszprunar, 1996; Hessler and Elofsson, 1995; Rivest, 1992; Ruppert, 1994; Weavers et al., 2009).

A very different cell type is the nephrocyte in tunicates. Tunicate nephrocytes represent a fraction of blood cells, which accumulate nitrogenous waste products inside voluminous vacuoles (Ballarin and Cima, 2005; Cima et al., 2014; George, 1939). A similar type of excretory cells is also present in the coelomic fluid of Bryozoa (Schwaha et al., 2020). Contrary to the excretory cells of insects and mollusks, nephrocytes in tunicates and bryozoans lack both ECM and a slit diaphragm and they represent specialized haemo- and coelomocytes, therefore they are evolutionarily unrelated to other excretory organs.

\section{Excretory organs and adaptations to new environments}

Excretory organs are not only responsible for the expulsion of metabolic waste products but they are also the primary organs for osmoregulation and ion balance (Larsen et al., 2014; Schmidt-Nielsen, 1997; Schmidt-Rhaesa, 2007). The maintenance of water balance is especially challenging in environments such as freshwater and terrestrial habitats, where water is excessive or sparse, respectively (Schmidt-Nielsen, 1997). Another problem related to osmoregulation is faced by the organisms inhabiting the brackish and intertidal realms, where salinity can rapidly and dramatically change in a short time span, which requires ability to accommodate to different salinity regimes (Schmidt-Nielsen, 1997). Moreover, differences in the environmental salinity and water availability result in adaptations regarding the mechanisms of ammonia (one of the most toxic metabolites) excretion, such as transforming it into less harmful nitrogenous end products (e.g. urea or uric acid) (Larsen et al., 2014; Needham, 1935; Schmidt-Nielsen, 1997; Weihrauch and O'Donnell, 2017). Therefore, modifications of excretory organs are believed to be crucial for colonizing new environments (Schmidt-Rhaesa, 2007). In fact, studies on various nephrozoans have shown that species inhabiting terrestrial, freshwater, brackish and intertidal environments exhibit species-specific adaptations in the morphology (e.g. (Krishnamoorthi, 1963; Randsø et al., 2019; Smith, 1984; von Nordheim and Schrader, 1994) and physiology (e.g. (Generlich and Giere, 1996; Needham, 1935; Schmidt-Nielsen, 1997; Smith, 1970; Werntz, 1963) of their excretory organs and these adaptations are not necessarily reflecting their evolutionary relationship. 


\section{Molecular identity of excretory organs: from development to function}

In contrast to the large number of detailed morphological descriptions of excretory organs in a variety of animals, molecular data are scarce. Most of the gene expression studies have been conducted in vertebrates (mainly mammals, fish and frogs) (summarized in (Desgrange and Cereghini, 2015) and a handful of invertebrates (mainly planarians and flies) (Scimone et al., 2011; Vu et al., 2015; Weavers et al., 2009) and have revealed not only common transcriptional programs governing the development of excretory organs, but also analogous sub-localization of solute transporters and structural proteins within the differentiated excretory compartments (Figure 4). Moreover, physiological studies in a large array of animals have shown that a number of ammonium transporters and proton pumps have conserved roles in excretory processes (Weihrauch and O'Donnell, 2017).

\section{Nephron development}

Kidneys, the excretory organs of vertebrates, emerge from the intermediate mesoderm and develop through a sequential formation of up to three organs: pronephros, mesonephros and metanephros (Figure 3) (Saxén and Saxén, 1987). Pronephros and mesonephros are only transient structures in amniotes and function as the fetal excretory organs, whilst metanephros is the definitive adult kidney. In fish and frogs, the adult kidney is the mesonephros that replaces the embryonic pronephros. Both mesonephros and metanephros are composed from a basic structural and functional unit, the nephron, which shows a comparable regional organization (Wingert and Davidson, 2008). The formation of kidneys is dictated by similar genetic interactions and morphogenetic events (Desgrange and Cereghini, 2015) (Figure 4).

Nephron development in mammals starts with a mesenchyme-to-epithelial transition (MET) of the anterior intermediate mesoderm (IM) and the specification of renal progenitor cells. This process is induced by the interplay of an ectodermal BMP4 signaling (James and Schultheiss, 2005) and the expression of odd skipped related gene (osr1) (James et al., 2006) and Ihx1 transcription factors (Tsang et al., 2000). Pax2 and pax8 genes are activated shortly after and act redundantly in the nephric lineage specification (Bouchard et al., 2002). The renal progenitor cells will form an epithelial tubule, the future nephric duct. As the tubule extends posteriorly, a number of transcription factors, such as hox11, six1/2/4, eya, sall, pax2, foxc and wt1 (Brophy et al., 2001; Kobayashi et al., 2008; Kreidberg et al., 1993; Kume et al., 2000; Nishinakamura et al., 2001; Sajithlal et al., 2005; Wellik et al., 2002; Xu et al., 2003) are expressed along its anterior-posterior axis and induce the expression of gdnf (Gong et al., 2007; Moore et al., 1996). Ret/Gdnf signaling is crucial for the outgrowth and 
branching of the ureteric bud (UB) at the posterior end of the nephric duct, which grows into medially positioned metanephric mesenchyme, which in turn gives rise to a renal vesicle (Costantini and Shakya, 2006). Other signaling pathways involved in UB formation and branching include Wnt (Bridgewater et al., 2008; Carroll et al., 2005; Kispert et al., 1998), sonic hedgehog (Shh) (Cain and Rosenblum, 2011), bone morphogenic protein (Bmp) (Nishinakamura and Sakaguchi, 2014) and fibroblast growth factor (Fgf) (Bates, 2011). Eventually, each renal vesicle forms a nephron through a series of morphogenetic movements and patterning events. Mafb, wt 1 and $I m x 1 b$ drive podocyte specification (Miner et al., 2002; Moriguchi et al., 2006) and Notch signaling together with pou3f3, hnf1b, irx1 and irx2 are responsible for the proximal tubule fates (Cheng et al., 2007; Heliot et al., 2013; Nakai et al., 2003). The specification of distal tubule is controlled from the molecular interplay of several transcription factors, including lef1, sox9 and Ihx1 (Mugford et al., 2009). 
regeneration of planarian protonephridium

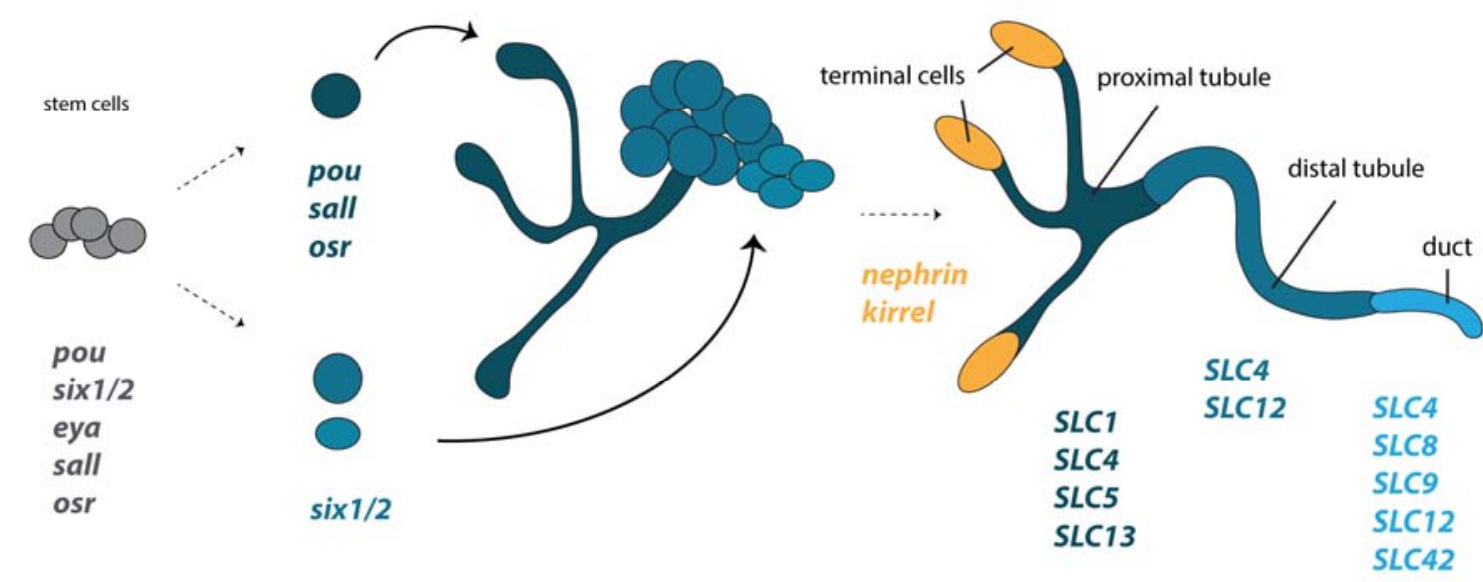

development of vertebrate kidney

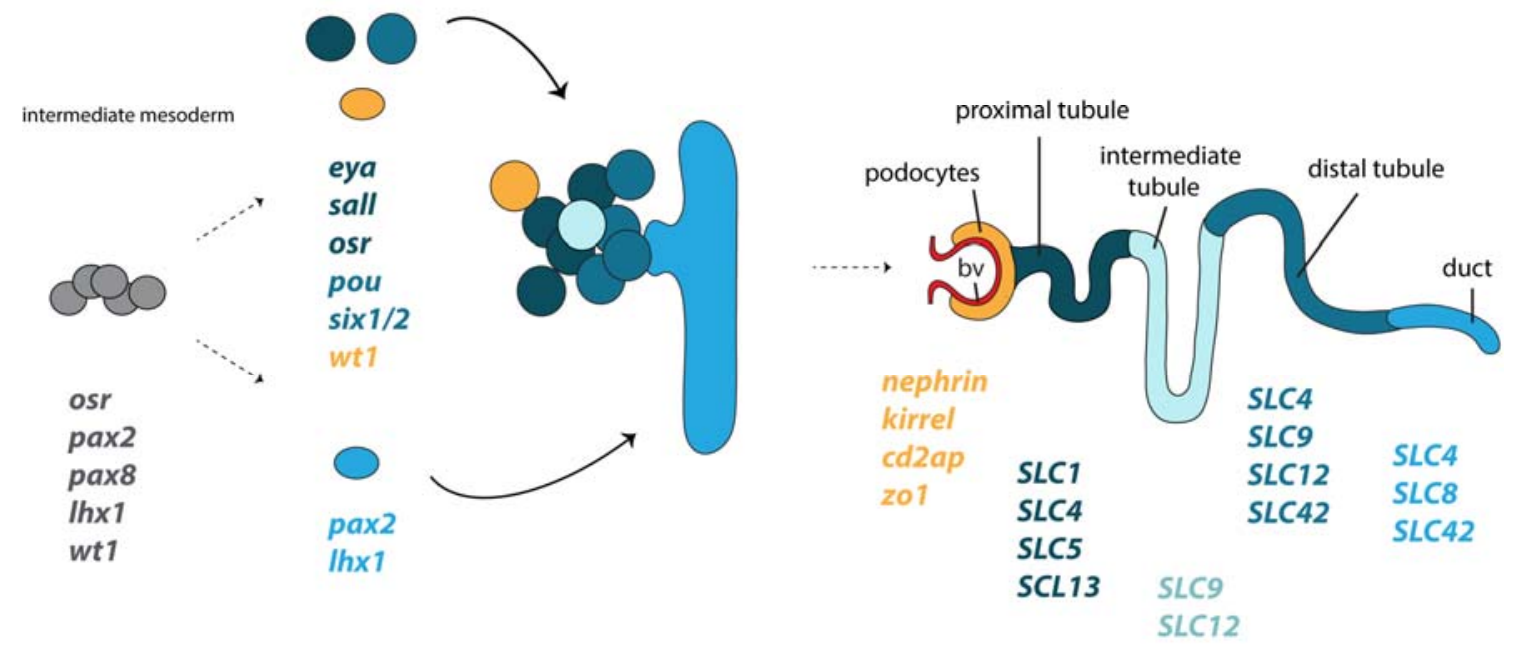

Figure 4. Development and structural correspondences of protonephridia and kidneys. Cartoon depiction of the molecular programs governing the regeneration of planarian protonephridia and the development of vertebrate kidneys, based on Scimone et al 2011 and Vu et al 2015. The corresponding structural components of protonephridia (terminal cell, tubule, duct) and kidneys (podocyte, tubule, duct) and the expression domains of orthologous genes in relation to their components, are color coded. Abbreviations: bv blood vessel.

In the zebrafish Danio rerio, the renal progenitor field forms from the lateral-most IM that express the transcription factors pax2a and pax8 (Pfeffer et al., 1998). Osr1 has also a conserved expression since its endodermal expression during gastrulation promotes renal lineages at the expense of blood/vascular ones (Mudumana et al., 2008). The renal progenitors adopt an epithelial state through MET and form an epithelial tubule. Cells located 
in the anterior-most domain express wt1a, wt1b, osr1, foxc1a and Ihx1a (O'Brien et al., 2011; Perner et al., 2007; Tomar et al., 2014) and will form the podocytes, whilst the remaining cells will give rise to the proximal and distal tubule and express jagged, irx $3 b$, evil and pou3f3a/pou3f3b (Li et al., 2014; Ma and Jiang, 2007; Wingert et al., 2007). The transcriptional interplay responsible for the formation of this boundary consists from pax2a, which forms a negative feedback loop with wt1a (Majumdar et al., 2000) and hnf1b, a suppressor of pax2a (Naylor et al., 2013). Tubule regionalization is also regulated by Retinoic Acid ( $\mathrm{Ra}$ ) signaling pathway (Wingert et al., 2007).

In the frog Xenopus, the renal progenitors emerge after a MET of the caudo-lateral IM resulting in the formation of a tubule. Once again, osr1 and osr2 are upstream of the specification of the renal progenitor field (Tena et al., 2007). The first renal molecular markers are $I h x 1$ and pax8, followed by the expression of pax2, wt1 and $h n f 1 \beta$ (Buisson et al., 2015; Carroll and Vize, 1996, 1999; Carroll et al., 1999; Wild et al., 2000). Wt1 specifies the future glomerulus whilst pax 2 is restricted to the future tubular region. The subdivision of the nephron into segments is governed by evi1 expression in the distal tubule and pronephric duct (Van Campenhout et al., 2006) and irx1, irx2 and irx3 expression in the proximal and intermediate tubule (Alarcon et al., 2008). The developing podocytes are specified from a cross talk between wt1, foxc2, Imx1b and mafb genes (Haldin et al., 2008; White et al., 2010). Signaling pathways with crucial roles in Xenopus nephrogenesis involve Wnt (Lavery et al., 2008; Saulnier et al., 2002; Tetelin and Jones, 2010), Fgf (Urban et al., 2006), Bmp (Bracken et al., 2008), Notch (McLaughlin et al., 2000; White et al., 2010) and Ra (Cartry et al., 2006).

\section{Protonephridial development}

Although there are several morphological descriptions on protonephridial development (Baeumler et al., 2011; Bartolomaeus, 1985; Hasse et al., 2010; Rohde et al., 1988; Temereva and Malakhov, 2006; Wenning et al., 1993), molecular studies are extremely limited. The most detailed work has been performed on the planarian Schmidtea mediterranea (Scimone et al., 2011) that has shown a remarkable conservation of the molecular programs between the regeneration of planarian protonephridia and the development of vertebrate kidneys (Figure 4). Planarian protonephridia consists of four cells types, the flame (terminal) cell, the ciliated tubule cell type (proximal tubule), the tubuleassociated cell type (distal tubule) and the duct. Regeneration and RNAi experiments on amputated animals showed a conserved function of eya, six1/2, pou3, hunchback, sall and osrgenes in the regeneration and maintenance of protonephridia. Eya, six1/2, pou3, sall and osr are expressed in the specified progenitor cells, whose fate segregates and results in the 
formation of the ciliated tubule cell type and the tubule-associated cell type. The ciliated tubule cell type continues to express pou3, sall and osr, whilst the tubule-associated cells express six1/2 (Scimone et al., 2011).

The conserved role of pou3 is also reported in the nematode $C$. elegans, where an orthologous gene, ceh- 6 is required for the formation and function of its excretory cell (Burglin and Ruvkun, 2001). Other conserved nephrogenesis-related transcription factors has been shown to be pax3 in the developing nephridia of the leech Helobdella robusta (Woodruff et al., 2007), pax2/5/8 in the nephridium of the cephalochordate Branchiostoma floridae (Kozmik et al., 1999) and sall in the protonephridium precursors of the polychaete Hydroides elegans (Arenas-Mena, 2013).

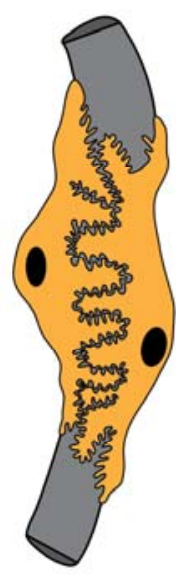

podocytes

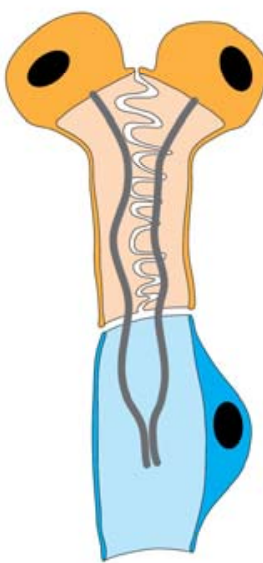

composite filter

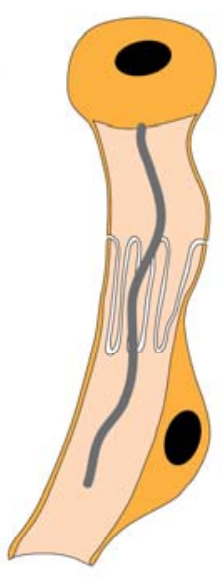

weir

intercellular

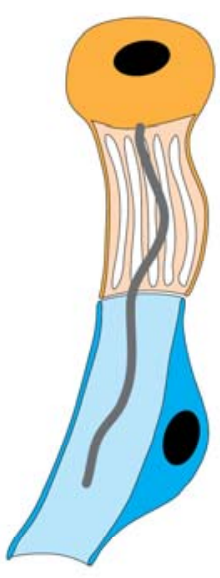

slits

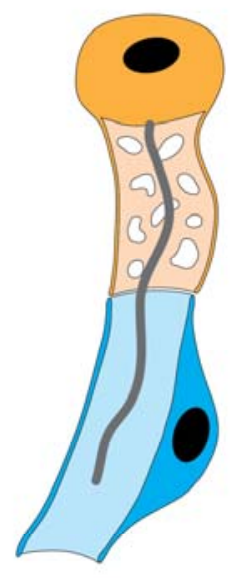

pores

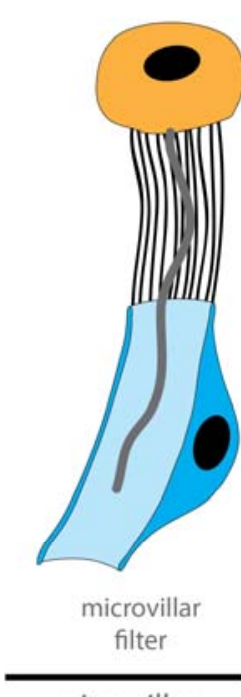

microvillar

Figure 5. Diversity of filter-forming cells within nephridia. The filter apparatus can be formed by different cell features. Intercalated cells form the filtration apparatus between cells, filtration can be performed by cellular pores and slits or microvilli can build up the filtration apparatus. Cells forming extracellular filter are depicted in orange, while nephroduct cells in blue.

\section{Development of insect Malpighian tubules}

The Malpighian tubules of insects consist of two cell types; the primary cell (PC) and the secondary (stellate) cell (SC). In Drosophila, these two cell types have a different developmental origin; while the PC derive from an ectodermal primordium at the hindgut/midgut junction and form the Malpighian tubule epithelium, the SC originate from the posterior mesoderm and invades the tubule epithelium through MET (Denholm et al., 2003). The molecular patterning of Malpighian tubule development appears quite different compared to the protonephridia and kidneys. Krüppel and cut expression in a cluster of cells 
of the hindgut marks the onset of PC development due to a Wnt signaling. Once specified, these cluster of cells start to form bud-like branches under the control of Decapentaplegic (BMP) signaling and Brinker (Hatton-Ellis et al., 2007). Later on, a regulatory interplay between cut, barr, three rows, pebble, pimples, trachealess, ribbon, raw, crooked neck, faint sausage, pant and schnurri, under a DPP/BMP signal, will result in the formation and morphogenesis of tubules (Hatton-Ellis et al., 2007; Jack and Myette, 1999; Shim et al., 2001). As the tubules elongate, a caudal mesodermal population that will become SC, express the transcription factors tiptop and teashirt, undergo MET and intercalate in the tubule (Denholm et al., 2003). The developmental process of Malpighian tubule development is overall conserved, since studies in Tribolium have shown that the onset, morphogenesis and molecular profile are similar. An important difference is the fact that in Drosophila only differentiated PC are expressing cut, whilst in Tribolium cut is expressed in both PC and SC (King and Denholm, 2014).

\section{Molecular basis of functional compartmentalization}

The terminal differentiated excretory organs are highly specialized and compartmentalized into discrete segments, composed of distinct epithelial cell types that carry out different functions. Each region is characterized by the expression of a set of structural proteins and transporters, involved in excrete ultrafiltration and modification, such as glucose and solute transport, and homeostasis. The spatial distribution of these proteins on the different segments of excretory organs is, once more, remarkably conserved (Figure 4) (Kozmik et al., 1999; Vu et al., 2015; Weavers et al., 2009).

In vertebrates, the nephron is divided in five segments: the glomerulus, the proximal, intermediate and distal tubule, and the collecting duct. Glomerulus has a central role in ultrafiltration and is expressing a set of membrane-associated proteins, such as Nephrin (NPHS1), KIRREL1 (NEPH1), CD2AP, ZO1, Nck and Stomatin/Podocin (summarised in (Patari-Sampo et al., 2006)). The tubular segments are further subdivided in smaller regions; each of them specialized in different aspects or excrete modification. The segmental organization is highly conserved, with the solute carrier (SLC) protein family to be sequentially expressed along the tubular segments of different types of nephrons, defining their boundaries (Desgrange and Cereghini, 2015). SLCs are membrane transporters, composed from 52 families, which can transport a number of different substrates (Hediger et al., 2013). In both mammalian metanephros and Xenopus pronephros, subsets of cells of the proximal tubule are specialized in reabsorbing: a) salts, expressing members from the bicarbonate transporter SLC4, sodium- and chloride-dependent neurotransmitter transporter SLC6, sodium/proton exchanger SLC9, sodium-sulfate/carboxylate cotransporter SLC13 and 
organic cation/anion/zwitterion transporter SLC22 families; b) amino acids, expressing members from the glutamate and neutral amino acid transporter SLC1, heavy subunits of the heteromeric amino acid transporter SLC3 and cationic/glycoprotein-associated amino acid transporter SLC7 families; and c) glucose, expressing members from the sodium-glucose cotransporter SLC5 family (Landowski et al., 2008; Raciti et al., 2008). SLC9a3 expression is also marking the proximal tubule of the pronephros of $D$. rerio, suggesting a similar function of this segment in reabsorbing sodium (Wingert et al., 2007). The intermediate tubule of nephron (Henle's loop) is facilitating the concentration of excretes and does not share an extensive molecular conservation among the different nephron types (Desgrange and Cereghini, 2015). Cells of the distal tubule are specialized in the reabsorption and secretion of ions, ammonium and water through the SLC9 and the electroneutral cation-chloride cotransporter SLC12. Common transporters characterizing the distal tubule of mammalian metanephros and Xenopus pronephros are members of SLC12, monocarboxylate transporter SLC16, type III sodium-phosphate cotransporter SLC20 and ammonium transporter SLC42/Rhesus families (Landowski et al., 2008; Raciti et al., 2008). Cells comprising the distal tubule of Xenopus are additionally expressing SLC4a4 (Raciti et al., 2008), whilst in D. rerio only members of the SLC12 family are seen (Wingert et al., 2007). Finally, the collecting duct consists from highly specialized, electrically tight cell types with dedicated roles in reabsorption and secretion of salts and water, and the concentration and preparation of the urine. In mammals, the collecting duct expresses members of the sodium/potassium exchanger SLC8, SLC16, SLC20, SLC22 and SLC42/Rhesus families (Landowski et al., 2008), while in Xenopus the analogous segment, the collecting tubule, expresses additionally SLC12a3 and doesn't express SLC42/Rhesus (Raciti et al., 2008). Even bigger differences we encounter in $D$. rerio, where the pronephric duct is not expressing any of these transporters (Wingert et al., 2007). The fact that the distal tubule of D. rerio and Xenopus pronephros expresses SLC12a3 and Xenopus do not express SLC42/Rhesus in their collecting tubule but only in their distal tubule, suggests that the function of distal tubule of $D$. rerio and Xenopus might be analogous to a mammalian tubule/duct hybrid (Desgrange and Cereghini, 2015). Another family of transporters that exhibit a nephron segment-specific expression is the one of aquaporins, which transports mainly water, urea and glycerol (Gomes et al., 2009). In mammals, the proximal tubule is expressing the water/nitrate/chloride transporter AQ1 (Nielsen et al., 1993), the aquaglyceroporin AQ7 (Nejsum et al., 2000), the water/ammonia transporter AQ8 (Elkjaer et al., 2001) and the super-aquaporin AQ11 (Morishita et al., 2005), while the collecting duct expresses the water transporters AQ2 (Fushimi et al., 1993) and AQ4 (Terris et al., 1995), the aquaglyceroporin AQ3 (Ecelbarger et al., 1995), the water/nitrate/chloride transporter AQ6 (Yasui et al., 1999) and AQ8. In Xenopus, a similar distribution of the AQ2 and AQ3 
mammalian orthologs has been shown in the collecting duct. However, AQ1 expression was restricted in glomerulus, in contrast to what is observed in mammals (Pandey et al., 2010). The situation looks even more different in teleosts where the proximal tubules express one AQ8, one AQ10-like and one AQ3 paralog (Engelund and Madsen, 2015; Santos et al., 2004). Moreover, two copies of $A Q 1$ have a renal expression but have acquired different functions; AQ1a is expressed in the proximal tubule and AQ1b in the distal tubule (Engelund and Madsen, 2015; Madsen et al., 2011). Finally, one AQ11 and one AQ12 ortholog are also expressed in the teleost nephron but the exact expression domain has not yet been revealed (Kim et al., 2014; Madsen et al., 2014).

In the planarian $S$. mediterranea protonephridia are divided in four major compartments: the flame (terminal) cells, the proximal tubule, the distal tubule and the duct. The flame cells are performing ultrafiltration and express Nephrin/Kirrel. In a similar fashion with the metanephridial systems, the tubular compartments are further subdivided in smaller specialized domains with different cell types being defined by the expression of a suite of SLC transporters and having diverse roles in excrete modification (Vu et al., 2015). For instance, the proximal tubule, primarily responsible for the recovery of filtered substances and reabsorption of salts, is expressing members from the SLC1, SLC5, SLC4, SLC6, SLC13 and SLC22 families. The distal tubule has a central role in homeostasis and expresses members from the SLC4 and SLC12 families, which are also marking the duct. The duct is additionally expressing SLC42/Rhesus, as seen in mammals but not in $D$. rerio and Xenopus, and a number of other SLCs, which mark the proximal tubule of vertebrates, such as SLC6, SLC7, SLC9 indicating a role of the planarian duct not only in the urine concentration but also in reabsorption of salts and amino acids. Interestingly, aquaporins are not expressed in any of the protonephridial compartments, suggesting divergent functions of these transporters in planarians (Vu et al., 2015).

Malpighian tubules of some insects (e.g. the fly Drosophila melanogaster and the mosquito Aedes aegypti) are also divided in distinct compartments with different physiological functions: the initial, transitional, main and lower segments, and the ureter (Beyenbach et al., 1993; Sozen et al., 1997). Each segment is populated by a different numeral and positional combination of PC and SC cells, depending on the investigated species. Overall, the initial and transitional segments are not participating in secretion but rather act as storage segments and transport (Dow et al., 1994; Dube et al., 2000). The main segment has both secretory and absorptive roles of salts and water and generates the primary urine. The PC cells of the main segment express a basolateral sodium/potassium transporter (Torrie et al., 2004), an inward-rectifier potassium transporter (Kir) (Evans et al., 2005), sodium/proton exchangers of the NHA and NHE (SLC9) families (Pullikuth et al., 2006; Rheault et al., 2007) and an aquaporin (Kaufmann et al., 2005). In contrast, the SC cells, which exhibit mostly an 
absorptive role, express mainly a chloride transporter and an aquaporin (Kaufmann et al., 2005; Kolosov and O'Donnell, 2020; O'Connor and Beyenbach, 2001; O'Donnell et al., 1998). The expression of SLC4 exchanger has also been reported in the SC cells of some species (Linser et al., 2012; Piermarini et al., 2010). Finally, the lower segment and rectum are mostly dedicated in the reabsorption of salts and water and the concentration of urine (O'Donnell and Maddrell, 1995).

Molecular similarities found at the building blocks of the ultrafiltration sites of protoand metanephridial systems are also seen in individual ultrafiltration cells. The membraneassociated protein complex composed of Nephrin, Kirrel, Cd2ap, Zo1 and Stomatin/Podocin is also forming the slit diaphragm of nephrocytes of the fly Drosophila melanogaster (Weavers et al., 2009; Zhuang et al., 2009) that performs filtration of the haemolymph (Weavers et al., 2009; Wigglesworth, 1943; Zhang et al., 2013). Nephrocytes are not only involved in ultrafiltration but also in protein reabsorption, via receptors such as Cubilin and Amnionless (AMN), similarly to mechanisms encountered in the renal proximal tubule cells (Zhang et al., 2013). Moreover, Nephrin/Kirrel expression has been described in the ultrafiltration apparatus of rhogocytes of the snail Biomphalaria glabrata (Kokkinopoulou et al., 2014), through which proteins and ions are filtered (Kokkinopoulou et al., 2015).

\section{Nitrogenous waste excretion}

One of the main and most toxic products of excretion in animals is nitrogenous waste. Nitrogenous waste products are the result of the amino acid catabolism (Campbell, 1991) and exist in three forms: ammonia, urea, or uric acid. Most aquatic species excrete ammonia, due to its high solubility in water, whilst semi-aquatic and terrestrial species usually convert ammonia to less hazardous and less soluble forms, such as urea and uric acid. Ammonia can occur either in its gaseous (NH3) or in its ionic form (NH4+); however, due to the high pK of $\mathrm{NH} 3$, in physiological solutions the vast amount of ammonia exists as $\mathrm{NH} 4+$. The excretory process of ammonia has been investigated in a large array of animals and shown extensive conservation of the repertoire of the ammonia transporters and proton pumps, independently of the presence of specialized excretory organs (Weihrauch and O'Donnell, 2017).

In kidneys, the epithelial cells of the proximal tubule secrete ammonia apically into the luminal fluid. A significant fraction of this ammonia secretion occurs via $\mathrm{Na}+\mathrm{NH} 4+$ exchange by the sodium/proton exchangers SLC9 (NHE) and some also takes place via diffusion (Bourgeois et al., 2010; Knepper et al., 1989; Preisig and Alpern, 1990). Almost all secreted ammonia is reabsorbed by cells of the thick ascending limb of Henle's loop into the interstitium, both by $\mathrm{K}+/ \mathrm{NH} 4+$ exchange of the apical cation-chloride cotransporter SLC12 
(NKCC) (Good, 1994) and Na+/NH4+ exchange of the basolateral SLC9 exchangers (Blanchard et al., 1998). Another cotransporter that plays an important role in $\mathrm{NH} 4+$ reabsorption is the basolateral bicarbonate transporter SLC4, which drives $\mathrm{NH3}$ diffusion across the basolateral membrane due to the bicarbonate transport into the cell and the subsequent rise of the intracellular pH (Good et al., 1984; Lee et al., 2010). The accumulated ammonia in the interstitium is forming a gradient that drives diffusion across the epithelium of the cells of the collecting duct and secretion of the concentrated ammonia to the lumen. This process is also supported by an proton gradient formed by the apical vacuolar H+-ATPase, which creates an acidic environment facilitating NH4+ entrapment (Flessner et al., 1991; Star et al., 1987) and a basolateral $\mathrm{Na}+\mathrm{K}+$ ATPase (NKA) that actively transfers ammonia by $\mathrm{Na}+\mathrm{NH}_{4}{ }^{+}$exchange (Wall, 1996). Finally, the Rhesus ammonia transporters (RhBG and $\mathrm{RhCG}$ ), spatially restricted to the collecting duct, also participate to the secretion to the lumen and preparation of the urine (Mak et al., 2006).

Species-specific excretory organs/sites have also recruited these transporters for excreting ammonia. In Malpighian systems, ammonia is firstly secreted into the Malpighian tubules and then actively absorbed by the hindgut and midgut, which express the ammonia transporter Rhesus, sodium/proton exchangers (NHE) and a vacuolar H+-ATPase (Blaesse et al., 2010; Weihrauch, 2006). Similarly, in the posterior rectum (anal papillae) of the aquatic mosquito larvae Aedes aegypti, the ammonia transporters Rhesus and the Rhesus-related AMTs, as well as a basal NKA and an apical vacuolar H+-ATPase are involved in ammonia excretion (Chasiotis et al., 2016; Durant and Donini, 2018). In the excretory H-system of the nematode $C$. elegans, ammonia enters the excretory cells via the basolateral NKA and potassium transporters and then diffuses across the apical membrane through an acidtrapping mechanism (Adlimoghaddam et al., 2015). Rhesus and the vacuolar H+-ATPase are likely also involved in ammonia excretion in the plicate organ of mussels of the Mytilus family (Thomsen et al., 2016). Other animal-specific ammonia excretory sites include the gills of several crustacean species and the branchial appendages of the marine annelid Eurythoe complanata, which all seem to express NKA, the vacuolar $\mathrm{H}_{+}-\mathrm{ATPase}$, Rhesus, as well as AMTs (in the case of the E. complanata) (Si et al., 2018; Thiel et al., 2017; Weihrauch et al., 2017). Interestingly, NKA, NHE, Rhesus and the vacuolar H+-ATPase are also reported to be involved in ammonia excretion even when this process is occurring through the integument, as shown in the leech Nephelopsis obscura (Quijada-Rodriguez et al., 2015), the planarian S. mediterranea (Weihrauch et al., 2012) and the nematode C. elegans (Adlimoghaddam et al., 2016), or through digestive-associated tissues, as suggested in members of the Xenacoelomorpha and Cnidaria (Andrikou et al., 2019).

The astonishing reported molecular similarities, not only at the developmental level but also at the structural and functional level of excretory systems, has led some authors to 
propose their common evolutionary origin (Haszprunar, 1996; Ruppert, 1994; Scimone et al., 2011; Vu et al., 2015; Weavers et al., 2009). However, given the fact that correspondences in molecular patterning cannot be the only criterion for supporting homology, especially in the level of a complex organ system, such as a nephridium, these interpretations need to be handled with caution.

\section{The problem of homology}

Although excretory organs are present across the Nephrozoa, their emergence and evolutionary relationship remain unsolved. When mapping nephridia on the recent animal phylogeny it is likely that the protonephridia are the ancestral form, from which at least the metanephridia evolved (Bartolomaeus and Ax, 1992; Ruppert, 1994). The evolution of metanephridia has likely happened multiple times independently, given that coeloms emerged convergently at different animal lineages (Koch et al., 2014). The fact that protonephridia can directly develop into metanephridia in some lineages indicates a close evolutionary relationship between these two types of excretory organs (Bartolomaeus and Ax, 1992; Ruppert, 1994). The homology of protonephridia and metanephridia is partly supported by similar transcription factors that seem to be involved in patterning both structures (Scimone et al., 2011). However, the taxon sampling is, so far, very narrow and therefore needs to be extended to solidify this interpretation.

So far, the cell type perspective does not contribute much to the question on the homology of excretory organs, mainly because it is dealing with a different level of homology (Abouheif, 1997). Firstly, excretory organs are composed of different cells that perform diverse functions. At what time in evolutionary history these cells originated and - if homologous - have been assembled to a functional organ, remains unclear. Secondly, the different cells that build a nephridium can perform similar functions with very different structures, which could speak for their convergence. When comparing for example the terminal ultrafiltration cell with other cell types that possess a "collar" or slit-like openings, it is evident that these collar-like structures within nephridia are highly diverse and therefore difficult to compare between species (Figure 5). Sometimes the filters are formed between the cells, sometimes the openings are within the cells, and in other cases these slits are formed by microvilli. All variations perform a similar task, namely the filtering of the primary urine. Do these differences speak for a convergence of the cells or even of the whole organ? On which level can these cellular structures be homologous? Can one use the presence of microvilli to state cell type homology or can we only homologize the microvilli themselves? It is clear that a cell is composed out of many different substructures that might have to be treated separately when investigating their origin (Carvalho-Santos et al., 2011; Sebe-Pedros 
et al., 2013). This raises the question of how many substructures are necessary to characterize a "cell type" and whether these are sufficient to homologize these cell types between species?

Additional problems are introduced when transcriptomic similarities are used for characterizing a cell type. The transcriptomic differences between cell-types and cell-states is a continuum, meaning that clear boundaries are established by the observer, and are therefore artificial (Trapnell, 2015). It is furthermore in the nature of a cell that transcriptomic noise (and in some cases technical noise), which can be to some extend stochastic, obscures the potential signal that could be used to characterize the cell type/state (Ballouz et al., 2019). But what kind of signal are we looking for? As mentioned already, subcellular structures that are plesiomorphic for a clade (e.g. cilia, microvili for Metazoa) may provide a signal, but cannot be used to homologize cell-types. Some authors propose the use of a combination of transcription factors and effector genes to detect cell types within transcriptomes (Arendt et al., 2016). Considering what we know about gene regulatory networks and their flexibility and evolutionary exchangeability of key-regulators within these networks, using "this gene combination" as definitions of cell type can lead to wrong conclusions, especially when taking into account false positives and false negatives. Moreover, the concentration of transcription factors on the protein level may impact the output of a gene regulatory network and cannot yet be detected with the current single-cell methods (Marx, 2019). Finally, given the fact that the consideration of sets of co-expression of regulators and effectors without functional testing is very arbitrary, how do we then discriminate between homoplasy and homology? (Shafer, 2019; Tschopp and Tabin, 2017). In principle, we face similar problems in the homologization of cell types that we face with the homologization of other biological levels. Noise, drift of underlying structures and methodological problems may obscure the conclusions. The coming years of data harvesting, comparative analyses and developments in these technologies will guide the way for cell and organ comparisons between animals.

In summary, excretory systems with their structural and functional variation, diverse cellular composition and variable embryology are an ideal showcase to test different approaches currently used for unravelling the origin of organ systems.

\section{References}

Abouheif, E., 1997. Developmental genetics and homology: a hierarchical approach. Trends Ecol Evol 12, 405-408. Adlimoghaddam, A., Boeckstaens, M., Marini, A.M., Treberg, J.R., Brassinga, A.K., Weihrauch, D., 2015. Ammonia excretion in Caenorhabditis elegans: mechanism and evidence of ammonia transport of the Rhesus protein CeRhr-1. J Exp Biol 218, 675-683.

Adlimoghaddam, A., O'Donnell, M.J., Kormish, J., Banh, S., Treberg, J.R., Merz, D., Weihrauch, D., 2016. Ammonia excretion in Caenorhabditis elegans: Physiological and molecular characterization of the rhr-2 knock-out mutant. Comp Biochem Physiol A Mol Integr Physiol 195, 46-54.

Ahlrichs, W., 1993a. Ultrastructure of the Protonephridia of Seison annulatus (Rotifera). Zoomorphology 113, $245-251$.

Ahlrichs, W.H., 1993b. On the protonephridial system of the brackish water rotifer Proales reinhardti (Rotifera, Monogononta). Microfauna Marina 8, 39-53.

Alarcon, P., Rodriguez-Seguel, E., Fernandez-Gonzalez, A., Rubio, R., Gomez-Skarmeta, J.L., 2008. A dual requirement for Iroquois genes during Xenopus kidney development. Development 135, 3197-3207. 
Andrikou, C., Thiel, D., Ruiz-Santiesteban, J.A., Hejnol, A., 2019. Active mode of excretion across digestive tissues predates the origin of excretory organs. PLoS Biol 17, e3000408.

Arab, A., Caetano, F.H., 2002. Segmental specializations in the Malpighian tubules of the fire ant Solenopsis saevissima Forel 1904 (Myrmicinae): an electron microscopical study. Arthropod Struct Dev 30, 281-292.

Arenas-Mena, C., 2013. Brachyury, Tbx2/3 and sall expression during embryogenesis of the indirectly developing polychaete Hydroides elegans. Int J Dev Biol 57, 73-83.

Arendt, D., Musser, J.M., Baker, C.V.H., Bergman, A., Cepko, C., Erwin, D.H., Pavlicev, M., Schlosser, G., Widder, S., Laubichler, M.D., Wagner, G.P., 2016. The origin and evolution of cell types. Nat Rev Genet 17, 744-757.

Baeumler, N., Haszprunar, G., Ruthensteiner, B., 2011. Development of the excretory system in the polyplacophoran mollusc, Lepidochitona corrugata: the protonephridium. J Morphol 272, 972-986.

Ballarin, L., Cima, F., 2005. Cytochemical properties of Botryllus schlosseri haemocytes: indications for morpho-functional characterisation. European Journal of Histochemistry, 255-264.

Ballouz, S., Pena, M.T., Knight, F.M., Adams, L.B., Gillis, J.A., 2019. The transcriptional legacy of developmental stochasticity. bioRxiv, 2019.2012.2011.873265.

Balser, E.J., Ruppert, E.E., 1990. Structure, Ultrastructure, and Function of the Preoral Heart Kidney in Saccoglossus kowalevskii (Hemichordata, Enteropneusta) Including New Data on the Stomochord. Acta Zoologica 71, 235-249.

Balser, E.J., Ruppert, E.E., 1993. Ultrastructure of Axial Vascular and Celomic Organs in Comasterid Featherstars (Echinodermata, Crinoidea). Acta Zoologica 74, 87-101.

Bartolomaeus, T., 1985. Ultrastructure and development of the protonephridia of Lineus viridis (Nemertini). Microfauna Marina 2, 61-83.

Bartolomaeus, T., 1989. Ultrastructure and relationship between protonephridia and metanephridia in Phoronis muelleri (Phoronida). Zoomorphology (Berlin) 109, 113-122.

Bartolomaeus, T., 1997. Ultrastructure of the renopericardial complex of the interstitial gastropod Philinoglossa helgolandica Hertling, 1932 (Mollusca: Opisthobranchia). Zoologischer Anzeiger 235, 165-176.

Bartolomaeus, T., Ax, P., 1992. Protonephridia and metanephridia - their relation within the Bilateria. Zeitschrift fuer Zoologische Systematik und Evolutionsforschung 30, 21-45.

Bartolomaeus, T., Quast, B., 2005. Structure and development of nephridia in Annelida and related taxa. Hydrobiologia 535-536, 139-165.

Bartolomaeus, T., Quast, B., Koch, M., 2009. Nephridial development and body cavity formation in Artemia salina (Crustacea: Branchiopoda): no evidence for any transitory coelom. Zoomorphology (Berlin) 128, 247-262.

Bates, C.H., J.; Sims-Lucas, S., 2016. Embryonic development of the Kidney, in: al., A.e. (Ed.), Pediatric Nephrology. Springer-Verlag, Berlin Heidelberg, pp. 3-36.

Bates, C.M., 2011. Role of fibroblast growth factor receptor signaling in kidney development. Pediatr Nephrol 26, 1373-1379.

Berridge, M.J., Oschman, J.L., 1969. A structural basis for fluid secretion by malpighian tubules. Tissue Cell 1, 247-272.

Beyenbach, K., Oviedo, A., Aneshansley, D., 1993. Malpighian tubules of Aedes aegypti: five tubules, one function. Journal of insect physiology 39, 639-648.

Bitsch, C., Bitsch, J., 2004. Phylogenetic relationships of basal hexapods among the mandibulate arthropods: a cladistic analysis based on comparative morphological characters. Zoologica Scripta 33, 511-550.

Blaesse, A.K., Broehan, G., Meyer, H., Merzendorfer, H., Weihrauch, D., 2010. Ammonia uptake in Manduca sexta midgut is mediated by an amiloride sensitive cation/proton exchanger: Transport studies and mRNA expression analysis of NHE7, 9, NHE8, and V-ATPase (subunit D). Comp Biochem Physiol A Mol Integr Physiol 157, 364-376.

Blanchard, A., Eladari, D., Leviel, F., Tsimaratos, M., Paillard, M., Podevin, R.A., 1998. NH4+ as a substrate for apical and basolateral $\mathrm{Na}(+)-$ $\mathrm{H}+$ exchangers of thick ascending limbs of rat kidney: evidence from isolated membranes. J Physiol 506 ( Pt 3), 689-698.

Bouchard, M., Souabni, A., Mandler, M., Neubuser, A., Busslinger, M., 2002. Nephric lineage specification by Pax2 and Pax8. Genes Dev 16, 2958-2970.

Bourgeois, S., Meer, L.V., Wootla, B., Bloch-Faure, M., Chambrey, R., Shull, G.E., Gawenis, L.R., Houillier, P., 2010. NHE4 is critical for the renal handling of ammonia in rodents. J Clin Invest 120, 1895-1904.

Bracken, C.M., Mizeracka, K., McLaughlin, K.A., 2008. Patterning the embryonic kidney: BMP signaling mediates the differentiation of the pronephric tubules and duct in Xenopus laevis. Dev Dyn 237, 132-144.

Bradley, T.J., 1983. Functional design of microvilli in the Malpighian tubules of the insect Rhodnius prolixus. J Cell Sci 60, 117-135.

Bridgewater, D., Cox, B., Cain, J., Lau, A., Athaide, V., Gill, P.S., Kuure, S., Sainio, K., Rosenblum, N.D., 2008. Canonical WNT/beta-catenin signaling is required for ureteric branching. Dev Biol 317, 83-94.

Briggs, R.T., Moss, B.L., 1997. Ultrastructure of the coxal gland of the horseshoe crab Limulus polyphemus: Evidence for ultrafiltration and osmoregulation. J Morphol 234, 233-252.

Brophy, P.D., Ostrom, L., Lang, K.M., Dressler, G.R., 2001. Regulation of ureteric bud outgrowth by Pax2-dependent activation of the glial derived neurotrophic factor gene. Development 128, 4747-4756.

Buisson, I., Le Bouffant, R., Futel, M., Riou, J.F., U mbhauer, M., 2015. Pax8 and Pax2 are specifically required at different steps of Xenopus pronephros development. Dev Biol 397, 175-190.

Bulger, R.E., 1965. The fine structure of the aglomerular nephron of the toadfish, Opsanus tau. Am J Anat 117, 171-191.

Burglin, T.R., Ruvkun, G., 2001. Regulation of ectodermal and excretory function by the $C$. elegans POU homeobox gene ceh-6. Development 128, 779-790.

Cain, J.E., Rosenblum, N.D., 2011. Control of mammalian kidney development by the Hedgehog signaling pathway. Pediatr Nephrol 26 , 1365-1371.

Campbell, J., 1991. Excretory nitrogen metabolism. Environmental and metabolic animal physiology 1, 277-325.

Carroll, T.J., Park, J.S., Hayashi, S., Majumdar, A., McMahon, A.P., 2005. Wnt9b plays a central role in the regulation of mesenchymal to epithelial transitions underlying organogenesis of the mammalian urogenital system. Dev Cell 9, 283-292.

Carroll, T.J., Vize, P.D., 1996. Wilms' tumor suppressor gene is involved in the development of disparate kidney forms: evidence from expression in the Xenopus pronephros. Dev Dyn 206, 131-138.

Carroll, T.J., Vize, P.D., 1999. Synergism between Pax-8 and lim-1 in embryonic kidney development. Dev Biol 214, 46-59.

Carroll, T.J., Wallingford, J.B., Vize, P.D., 1999. Dynamic patterns of gene expression in the developing pronephros of Xenopus laevis. Dev Genet 24, 199-207.

Cartry, J., Nichane, M., Ribes, V., Colas, A., Riou, J.F., Pieler, T., Dolle, P., Bellefroid, E.J., Umbhauer, M., 2006. Retinoic acid signalling is required for specification of pronephric cell fate. Dev Biol 299, 35-51. 
Carvalho-Santos, Z., Azimzadeh, J., Pereira-Leal, J.B., Bettencourt-Dias, M., 2011. Evolution: Tracing the origins of centrioles, cilia, and flagella. J Cell Biol 194, 165-175.

Chasiotis, H., lonescu, A., Misyura, L., Bui, P., Fazio, K., Wang, J., Patrick, M., Weihrauch, D., Donini, A., 2016. An animal homolog of plant Mep/Amt transporters promotes ammonia excretion by the anal papillae of the disease vector mosquito Aedes aegypti. J Exp Biol 219, 1346-1355.

Cheng, H.T., Kim, M., Valerius, M.T., Surendran, K., Schuster-Gossler, K., Gossler, A., McMahon, A.P., Kopan, R., 2007. Notch2, but not Notch1, is required for proximal fate acquisition in the mammalian nephron. Development 134, 801-811.

Chitwood, B.G., Chitwood, M.B., 1950. An introduction to nematology. Section I. Anatomy. An introduction to nematology. Section I. Anatomy.

Cima, F., Caicci, F., Sordino, P., 2014. The haemocytes of the salp Thalia democratica (Tunicata, Thaliacea): an ultrastructural and histochemical study in the oozoid. Acta Zoologica 95, 375-391.

Coons, L.B., L'Amoreaux, W.J., Rosell-Davis, R., Starr-spires, L., 1990. Fine structure of the fat body and nephrocytes in the life-stages of Dermacentor variabilis. Experimental \& applied acarology 8, 125-142.

Costantini, F., Shakya, R., 2006. GDNF/Ret signaling and the development of the kidney. Bioessays 28, 117-127.

Crossley, A.C., 1972. The ultrastructure and function of pericardial cells and other nephrocytes in an insect: Calliphora erythrocephala. Tissue and Cell 4, 529-560.

Denholm, B., Sudarsan, V., Pasalodos-Sanchez, S., Artero, R., Lawrence, P., Maddrell, S., Baylies, M., Skaer, H., 2003. Dual origin of the renal tubules in Drosophila: mesodermal cells integrate and polarize to establish secretory function. Curr Biol 13, 1052-1057.

Desgrange, A., Cereghini, S., 2015. Nephron Patterning: Lessons from Xenopus, Zebrafish, and Mouse Studies. Cells 4, 483-499.

Dilly, P.N., Welsch, U., Rehkamper, G., 1986. Fine-Structure of Heart, Pericardium and Glomerular Vessel in Cephalodiscus gracilis Mintosh, 1882 (Pterobranchia, Hemichordata). Acta Zoologica 67, 173-179.

Dobbs, G.H., Devries, A.L., 1975. Aglomerular Nephron of Antarctic Teleosts - Light and Electron-Microscopic Study. Tissue \& Cell 7, 159170.

Dow, J.A., Davies, S.A., 2001. The Drosophila melanogaster malpighian tubule.

Dow, J.A., Maddrell, S.H., Gortz, A., Skaer, N.J., Brogan, S., Kaiser, K., 1994. The malpighian tubules of Drosophila melanogaster: a novel phenotype for studies of fluid secretion and its control. J Exp Biol 197, 421-428.

Dressler, G.R., 2006. The cellular basis of kidney development. Annual Review of Cell and Developmental Biology 22, 509-529.

Dube, K., McDonald, D.G., O'Donnell, M.J., 2000. Calcium transport by isolated anterior and posterior Malpighian tubules of Drosophila melanogaster: roles of sequestration and secretion. J Insect Physiol 46, 1449-1460.

Durant, A.C., Donini, A., 2018. Evidence that Rh proteins in the anal papillae of the freshwater mosquito Aedes aegypti are involved in the regulation of acid-base balance in elevated salt and ammonia environments. J Exp Biol 221.

Ecelbarger, C.A., Terris, J., Frindt, G., Echevarria, M., Marples, D., Nielsen, S., Knepper, M.A., 1995. Aquaporin-3 water channel localization and regulation in rat kidney. Am J Physiol 269, F663-672.

Ehlers, U., 1992. Dermonephridia - modified epidermal cells with a probable excretory function in Paratomella rubra (Acoela, Plathelminthes). Microfauna Marina 7, 253-264.

Eichelberg, D., Wessing, A., 1975. Morphology of the Malpighian tubules of insects. Fortschritte der Zoologie.

El-Shoura, S., 1989. Ultrastructure of the larval haemocytes and nephrocytes in the tick Ornithodoros (Pavlovoskyella) erraticus (Ixodoidea: Argasidae). Acarologia 30, 35-40.

Elkjaer, M.L., Nejsum, L.N., Gresz, V., Kwon, T.H., Jensen, U.B., Frokiaer, J., Nielsen, S., 2001. Immunolocalization of aquaporin-8 in rat kidney, gastrointestinal tract, testis, and airways. Am J Physiol Renal Physiol 281, F1047-1057.

Engelund, M.B., Madsen, S.S., 2015. Tubular localization and expressional dynamics of aquaporins in the kidney of seawater-challenged Atlantic salmon. J Comp Physiol B 185, 207-223.

Evans, J.M., Allan, A.K., Davies, S.A., Dow, J.A., 2005. Sulphonylurea sensitivity and enriched expression implicate inward rectifier K+ channels in Drosophila melanogaster renal function. J Exp Biol 208, 3771-3783.

Ezhova, O.V., Lavrova, E.A., Malakhov, V.V., 2013. Microscopic anatomy of the axial complex in the starfish Asterias rubens (Echinodermata, Asteroidea). Biology Bulletin 40, 643-653.

Ezhova, O.V., Lavrova, E.A., Malakhov, V.V., 2014. The morphology of the axial complex and associated structures in Asterozoa (Asteroidea, Echinoidea, Ophiuroidea). Biologiya Morya (Vladivostok) 40, 165-177.

Flessner, M.F., Wall, S.M., Knepper, M.A., 1991. Permeabilities of rat collecting duct segments to NH3 and NH4+. Am J Physiol 260, F264272.

Fushimi, K., Uchida, S., Hara, Y., Hirata, Y., Marumo, F., Sasaki, S., 1993. Cloning and expression of apical membrane water channel of rat kidney collecting tubule. Nature 361, 549-552.

Garayoa, M., Villaro, A.C., Montuenga, L., Sesma, P., 1992. Malpighian tubules of Formica polyctena (Hymenoptera): light and electron microscopic study. Journal of Morphology 214, 159-171.

Generlich, O., Giere, O., 1996. Osmoregulation in two aquatic oligochaetes from habitats with different salinity and comparison to other annelids, Aquatic oligochaete biology VI. Springer, pp. 251-261.

George, W.C., 1939. Memoirs: A comparative study of the Blood of the Tunicates. Journal of Cell Science 2, 391-428.

Gérard, P., 1936. Comparative histophysiology of the vertebrate nephron. Journal of anatomy $70,354$.

Gerke, P., Huber, T.B., Sellin, L., Benzing, T., Walz, G., 2003. Homodimerization and heterodimerization of the glomerular podocyte proteins nephrin and NEPH1. Journal of the American Society of Nephrology 14, 918-926.

Gomes, D., Agasse, A., Thiebaud, P., Delrot, S., Geros, H., Chaumont, F., 2009. Aquaporins are multifunctional water and solute transporters highly divergent in living organisms. Biochim Biophys Acta 1788, 1213-1228.

Gong, K.Q., Yallowitz, A.R., Sun, H., Dressler, G.R., Wellik, D.M., 2007. A Hox-Eya-Pax complex regulates early kidney developmental gene expression. Mol Cell Biol 27, 7661-7668.

Good, D.W., 1994. Ammonium transport by the thick ascending limb of Henle's loop. Annu Rev Physiol 56, 623-647.

Good, D.W., Knepper, M.A., Burg, M.B., 1984. Ammonia and bicarbonate transport by thick ascending limb of rat kidney. Am J Physiol 247 , F35-44.

Goodrich, E.S., 1945. The study of Nephridia and genital ducts since 1895. Journal of Cell Science 2, 113-301.

Green, L.F.B., 1979. Regional Specialization in the Malpighian Tubules of the New Zealand Glow Worm Arachnocampa luminosa (Diptera, Mycetophilidae) - Structure and Function of Type-I and Type-II Cells. Tissue \& Cell 11, 673-702. 
Green, L.F.B., 1980. Cryptonephric Malpighian Tubule System in a Dipteran Larva, the New Zealand Glow Worm, Arachnocampa luminosa (Diptera, Mycetophilidae) - Structural Study. Tissue \& Cell 12, 141-151.

Greven, H., 1982. Homologues or analogues? A survey of some structural patterns in Tardigrada, Proceedings of the Third International Symposium on the Tardigrada (ed. DR Nelson), pp. 55-76.

Haldin, C.E., Masse, K.L., Bhamra, S., Simrick, S., Kyuno, J., Jones, E.A., 2008. The Imx1b gene is pivotal in glomus development in Xenopus laevis. Dev Biol 322, 74-85.

Hasse, C., Rebscher, N., Reiher, W., Sobjinski, K., Moerschel, E., Beck, L., Tessmar-Raible, K., Arendt, D., Hassel, M., 2010. Three consecutive generations of nephridia occur during development of Platynereis dumerilii (Annelida, Polychaeta). Dev Dyn 239, 1967-1976.

Haszprunar, G., 1996. The molluscan rhogocyte (pore-cell, Blasenzelle, cellule nucale), and its significance for ideas on nephridial evolution. Journal of Molluscan Studies 62, 185-211.

Hatton-Ellis, E., Ainsworth, C., Sushama, Y., Wan, S., VijayRaghavan, K., Skaer, H., 2007. Genetic regulation of patterned tubular branching in Drosophila. Proc Natl Acad Sci U S A 104, 169-174.

Hay-Schmidt, A., 1987. The ultrastructure of the protonephridium of the actinotroch larva (Phoronida). Acta Zoologica (Copenhagen) 68, 35-47.

Hazelton, S.R., Townsend, V.R., Richter, C., Ritter, M.E., Felgenhauer, B.E., Spring, J.H., 2002. Morphology and ultrastructure of the Malpighian tubules of the Chilean common tarantula (Araneae : Theraphosidae). Journal of Morphology 251, 73-82.

Hediger, M.A., Clemencon, B., Burrier, R.E., Bruford, E.A., 2013. The ABCs of membrane transporters in health and disease (SLC series): introduction. Mol Aspects Med 34, 95-107.

Heliot, C., Desgrange, A., Buisson, I., Prunskaite-Hyyrylainen, R., Shan, J., Vainio, S., Umbhauer, M., Cereghini, S., 2013. HNF1B controls proximal-intermediate nephron segment identity in vertebrates by regulating Notch signalling components and Irx1/2. Development 140 , 873-885.

Hessler, R. R., Elofsson, R., 1995. Segmental Podocytic Excretory Glands in the Thorax of Hutchinsoniella macracantha (Cephalocarida). Journal of Crustacean Biology 15, 61-69.

Holterman, M., van der Wurff, A., van den Elsen, S., van Megen, H., Bongers, T., Holovachov, O., Bakker, J., Helder, J., 2006. Phylum-wide analysis of SSU rDNA reveals deep phylogenetic relationships among nematodes and accelerated evolution toward crown clades. Molecular Biology and Evolution 23, 1792-1800.

Ichimura, K., Sakai, T., 2017. Evolutionary morphology of podocytes and primary urine-producing apparatus. Anatomical Science International 92, 161-172.

Jack, J., Myette, G., 1999. Mutations that alter the morphology of the malpighian tubules in Drosophila. Dev Genes Evol 209, 546-554.

James, R.G., Kamei, C.N., Wang, Q., Jiang, R., Schultheiss, T.M., 2006. Odd-skipped related 1 is required for development of the metanephric kidney and regulates formation and differentiation of kidney precursor cells. Development 133, 2995-3004.

James, R.G., Schultheiss, T.M., 2005. Bmp signaling promotes intermediate mesoderm gene expression in a dose-dependent, cellautonomous and translation-dependent manner. Developmental biology 288, 113-125.

Johnson, I.T., Riegel, J.A., 1977. Ultrastructural Studies on Malpighian Tubule of Pill Millipede, Glomeris marginata (Villers) - General Morphology and Localization of Phosphatase Enzymes. Cell Tissue Res 180, 357-366.

Jondelius, U., Ruiz-Trillo, I., Baguna, J., Riutort, M., 2002. The Nemertodermatida are basal bilaterians and not members of the Platyhelminthes. Zool. Scripta 31, 201-215.

Kapoor, N.N., 1994. A Study of the Malpighian Tubules of the Plecopteran Nymph Paragnetina media (Walker) (Plecoptera, Perlidae) by Light, Scanning Electron, and Transmission Electron Microscopy. Canadian Journal of Zoology-Revue Canadienne De Zoologie 72, 15661575.

Kaufmann, N., Mathai, J.C., Hill, W.G., Dow, J.A., Zeidel, M.L., Brodsky, J.L., 2005. Developmental expression and biophysical characterization of a Drosophila melanogaster aquaporin. Am J Physiol Cell Physiol 289, C397-407.

Khodabandeh, S., Charmantier, G., Blasco, C., Grousset, E., Charmantier-Daures, M., 2005. Ontogeny of the antennal glands in the crayfish Astacus leptodactylus (Crustacea, Decapoda): anatomical and cell differentiation. Cell Tissue Res 319, 153-165.

Kieneke, A., Ahlrichs, W.H., Arbizu, P.M., Bartolomaeus, T., 2008. Ultrastructure of protonephridia in Xenotrichula carolinensis syltensis and Chaetonotus maximus (Gastrotricha : Chaetonotida): comparative evaluation of the gastrotrich excretory organs. Zoomorphology 127, 120.

Kieneke, A., Hochberg, R., 2012. Ultrastructural observations of the protonephridia of Polymerurus nodicaudus (Gastrotricha: Paucitubulatina). Acta Zoologica 93, 115-124.

Kim, Y.K., Lee, S.Y., Kim, B.S., Kim, D.S., Nam, Y.K., 2014. Isolation and mRNA expression analysis of aquaporin isoforms in marine medaka Oryzias dancena, a euryhaline teleost. Comp Biochem Physiol A Mol Integr Physiol 171, 1-8.

King, B., Denholm, B., 2014. Malpighian tubule development in the red flour beetle (Tribolium castaneum). Arthropod Struct Dev 43, 605613.

Kispert, A., Vainio, S., McMahon, A.P., 1998. Wnt-4 is a mesenchymal signal for epithelial transformation of metanephric mesenchyme in the developing kidney. Development 125, 4225-4234.

Knepper, M.A., Packer, R., Good, D.W., 1989. Ammonium transport in the kidney. Physiol Rev 69, 179-249.

Kobayashi, A., Valerius, M.T., Mugford, J.W., Carroll, T.J., Self, M., Oliver, G., McMahon, A.P., 2008. Six2 defines and regulates a multipotent self-renewing nephron progenitor population throughout mammalian kidney development. Cell Stem Cell 3, 169-181.

Koch, M., Quast, B., Bartolomaeus, T., 2014. Coeloms and nephridia in annelids and arthropods. Deep metazoan phylogeny: the backbone of the tree of life. New insights from analyses of molecules, morphology, and theory of data analysis. De Gruyter, Berlin, 173-284.

Kokkinopoulou, M., Guler, M.A., Lieb, B., Barbeck, M., Ghanaati, S., Markl, J., 2014. 3D-ultrastructure, functions and stress responses of gastropod (Biomphalaria glabrata) rhogocytes. PLoS One 9, e101078.

Kokkinopoulou, M., Spiecker, L., Messerschmidt, C., Barbeck, M., Ghanaati, S., Landfester, K., Markl, J., 2015. On the Ultrastructure and Function of Rhogocytes from the Pond Snail Lymnaea stagnalis. PLoS One 10, e0141195.

Kolosov, D., O'Donnell, M.J., 2020. Mechanisms and regulation of chloride transport in the Malpighian tubules of the larval cabbage looper Trichoplusia ni. Insect Biochem Mol Biol 116, 103263.

Koriyama, Y., Yamada, E., Watanabe, I., 1992. Pored-Domes of the Fenestrated Endotheliocyte of the Glomerular and Peritubular Capillaries in the Rodent Kidney. Journal of Electron Microscopy 41, 30-36.

Kozmik, Z., Holland, N.D., Kalousova, A., Paces, J., Schubert, M., Holland, L.Z., 1999. Characterization of an amphioxus paired box gene, AmphiPax2/5/8: developmental expression patterns in optic support cells, nephridium, thyroid-like structures and pharyngeal gill slits, but not in the midbrain-hindbrain boundary region. Development 126, 1295-1304. 
Kreidberg, J.A., Sariola, H., Loring, J.M., Maeda, M., Pelletier, J., Housman, D., Jaenisch, R., 1993. WT-1 is required for early kidney development. Cell 74, 679-691.

Krishnamoorthi, B., 1963. Gross morphology and histology of nephridia in four species of polychaetes, Proceedings of the Indian Academy of Sciences-Section B. Springer India, pp. 195-208.

Kristensen, R.M., Hay-Schmidt, A., 1989. The Protonephridia of the Arctic Kinorhynch Echinoderes aquilonius (Cyclorhagida, Echinoderidae). Acta Zoologica 70, 13-27.

Kume, T., Deng, K., Hogan, B.L., 2000. Murine forkhead/winged helix genes Foxc1 (Mf1) and Foxc2 (Mfh1) are required for the early organogenesis of the kidney and urinary tract. Development 127, 1387-1395.

Kuzmina, T.V., Malakhov, V.V., 2015. The accessory hearts of the articulate brachiopod Hemithyris psittacea. Zoomorphology $134,25-32$. Lammert, V., 1985. The Fine-Structure of Protonephridia in Gnathostomulida and Their Comparison within Bilateria. Zoomorphology 105, 308-316.

Landowski, C.P., Suzuki, Y., Hediger, M.A., 2008. The mammalian transporter families, Seldin and giebisch's the kidney. Elsevier, pp. 91-146. Larsen, E.H., Deaton, L.E., Onken, H., O'Donnell, M., Grosell, M., Dantzler, W.H., Weihrauch, D., 2014. Osmoregulation and excretion. Comprehensive physiology 4, 405-573.

Lavery, D.L., Davenport, I.R., Turnbull, Y.D., Wheeler, G.N., Hoppler, S., 2008. Wnt6 expression in epidermis and epithelial tissues during Xenopus organogenesis. Dev Dyn 237, 768-779.

Lee, S., Lee, H.J., Yang, H.S., Thornell, I.M., Bevensee, M.O., Choi, I., 2010. Sodium-bicarbonate cotransporter NBCn1 in the kidney medullary thick ascending limb cell line is upregulated under acidic conditions and enhances ammonium transport. Exp Physiol 95, 926937.

Li, Q.L., Zhong, H.Y., Zhang, Y.L., Wei, C., 2015. Comparative morphology of the distal segments of Malpighian tubules in cicadas and spittlebugs, with reference to their functions and evolutionary indications to Cicadomorpha (Hemiptera: Auchenorrhyncha). Zoologischer Anzeiger 258, 54-68.

Li, Y., Cheng, C.N., Verdun, V.A., Wingert, R.A., 2014. Zebrafish nephrogenesis is regulated by interactions between retinoic acid, mecom, and Notch signaling. Dev Biol 386, 111-122.

Lindström, N.O., Tran, T., Guo, J.J., Rutledge, E., Parvez, R.K., Thornton, M.E., Grubbs, B., McMahon, J.A., McMahon, A.P., 2018. Conserved and Divergent Molecular and Anatomic Features of Human and Mouse Nephron Patterning. Journal of the American Society of Nephrology $29,825-840$

Linser, P.J., Neira Oviedo, M., Hirata, T., Seron, T.J., Smith, K.E., Piermarini, P.M., Romero, M.F., 2012. Slc4-like anion transporters of the larval mosquito alimentary canal. J Insect Physiol 58, 551-562.

Little, M., Georgas, K., Pennisi, D., Wilkinson, L., 2010. Kidney development: two tales of tubulogenesis, Current topics in developmental biology. Elsevier, pp. 193-229.

Lüter, C., 1995. Ultrastructure of the Metanephridia of Terebratulina retusa and Crania anomala (Brachiopoda). Zoomorphology 115, 99107.

Ma, M., Jiang, Y.J., 2007. Jagged2a-notch signaling mediates cell fate choice in the zebrafish pronephric duct. PLoS Genet 3, e18.

Maddrell, S., 1980. Characteristics of epithelial transport in insect Malpighian tubules, Current topics in membranes and transport. Elsevier, pp. 427-463.

Madsen, S.S., Bujak, J., Tipsmark, C.K., 2014. Aquaporin expression in the Japanese medaka (Oryzias latipes) in freshwater and seawater: challenging the paradigm of intestinal water transport? J Exp Biol 217, 3108-3121.

Madsen, S.S., Olesen, J.H., Bedal, K., Engelund, M.B., Velasco-Santamaria, Y.M., Tipsmark, C.K., 2011. Functional characterization of water transport and cellular localization of three aquaporin paralogs in the salmonid intestine. Front Physiol 2, 56.

Majumdar, A., Lun, K., Brand, M., Drummond, I.A., 2000. Zebrafish no isthmus reveals a role for pax2.1 in tubule differentiation and patterning events in the pronephric primordia. Development 127, 2089-2098.

Mak, D.O., Dang, B., Weiner, I.D., Foskett, J.K., Westhoff, C.M., 2006. Characterization of ammonia transport by the kidney Rh glycoproteins RhBG and RhCG. Am J Physiol Renal Physiol 290, F297-305.

Marx, V., 2019. A dream of single-cell proteomics. Nat Methods 16, 809-812.

Mayer, G., 2006. Origin and differentiation of nephridia in the Onychophora provide no support for the Articulata. Zoomorphology 125, 112.

Mayer, G., Bartolomaeus, T., 2003. Ultrastructure of the stomochord and the heart-glomerulus complex in Rhabdopleura compacta (Pterobranchia): phylogenetic implications. Zoomorphology 122, 125-133.

McLaren, D.J., 1974. The anterior glands of adult Necator americanus (Nematoda: Strongyloidea). I. Ultrastructural studies. Int J Parasitol 4, 25-37.

McLaughlin, K.A., Rones, M.S., Mercola, M., 2000. Notch regulates cell fate in the developing pronephros. Dev Biol 227, 567-580.

McMahon, A.P., 2016. Development of the mammalian kidney, Current topics in developmental biology. Elsevier, pp. 31-64.

Miner, J.H., Morello, R., Andrews, K.L., Li, C., Antignac, C., Shaw, A.S., Lee, B., 2002. Transcriptional induction of slit diaphragm genes by Lmx1b is required in podocyte differentiation. J Clin Invest 109, 1065-1072.

Møbjerg, N., Dahl, C., 1996. Studies on the morphology and ultrastructure of the Malpighian tubules of Halobiotus crispae Kristensen, 1982 (Eutardigrada). Zoological Journal of the Linnean Society 116, 85-99.

Møbjerg, N., Larsen, E.H., Jespersen, A., 2000. Morphology of the kidney in larvae of Bufo viridis (Amphibia, Anura, Bufonidae). Journal of Morphology 245, 177-195.

Moller, P.C., Ellis, R.A., 1974. Fine Structure of Excretory System of Amphioxus (Branchiostoma floridae) and Its Response to Osmotic Stress. Cell Tissue Res 148, 1-9.

Moore, M.W., Klein, R.D., Farinas, I., Sauer, H., Armanini, M., Phillips, H., Reichardt, L.F., Ryan, A.M., Carver-Moore, K., Rosenthal, A., 1996. Renal and neuronal abnormalities in mice lacking GDNF. Nature 382, 76-79.

Moriguchi, T., Hamada, M., Morito, N., Terunuma, T., Hasegawa, K., Zhang, C., Yokomizo, T., Esaki, R., Kuroda, E., Yoh, K., Kudo, T., Nagata, M., Greaves, D.R., Engel, J.D., Yamamoto, M., Takahashi, S., 2006. MafB is essential for renal development and F4/80 expression in macrophages. Mol Cell Biol 26, 5715-5727.

Morishita, Y., Matsuzaki, T., Hara-chikuma, M., Andoo, A., Shimono, M., Matsuki, A., Kobayashi, K., Ikeda, M., Yamamoto, T., Verkman, A., Kusano, E., Ookawara, S., Takata, K., Sasaki, S., Ishibashi, K., 2005. Disruption of aquaporin-11 produces polycystic kidneys following vacuolization of the proximal tubule. Mol Cell Biol 25, 7770-7779.

Mudumana, S.P., Hentschel, D., Liu, Y., Vasilyev, A., Drummond, I.A., 2008. odd skipped related1 reveals a novel role for endoderm in regulating kidney versus vascular cell fate. Development 135, 3355-3367. 
Mugford, J.W., Yu, J., Kobayashi, A., McMahon, A.P., 2009. High-resolution gene expression analysis of the developing mouse kidney defines novel cellular compartments within the nephron progenitor population. Dev Biol 333, 312-323.

Nakai, S., Sugitani, Y., Sato, H., Ito, S., Miura, Y., Ogawa, M., Nishi, M., Jishage, K., Minowa, O., Noda, T., 2003. Crucial roles of Brn1 in distal tubule formation and function in mouse kidney. Development 130, 4751-4759.

Naylor, R.W., Przepiorski, A., Ren, Q., Yu, J., Davidson, A.J., 2013. HNF1beta is essential for nephron segmentation during nephrogenesis. J Am Soc Nephrol 24, 77-87.

Needham, J., 1935. Problems of nitrogen catabolism in invertebrates: Correlation between uricotelic metabolism and habitat in the phylum Mollusca. Biochemical Journal 29, 238.

Nejsum, L.N., Elkjaer, M., Hager, H., Frokiaer, J., Kwon, T.H., Nielsen, S., 2000. Localization of aquaporin-7 in rat and mouse kidney using RTPCR, immunoblotting, and immunocytochemistry. Biochem Biophys Res Commun 277, 164-170.

Nelson, F.K., Albert, P.S., Riddle, D.L., 1983. Fine Structure of the Caenorhabditis elegans Secretory Excretory System. Journal of Ultrastructure Research 82, 156-171.

Neuhaus, B., 1988. Ultrastructure of the Protonephridia in Pycnophyes kielensis (Kinorhyncha, Homalorhagida). Zoomorphology 108, 245253.

Neuhaus, B., Kristensen, R.M., 2007. Ultrastructure of the protonephridia of larval Rugiloricus cf. cauliculus, male Armorioricus elegans, and female Nanaloricus mysticus (Loricifera). Journal of Morphology 268, 357-370.

Nicholls, S.P., 1983. Ultrastructural Evidence for Paracellular Fluid-Flow in the Malpighian Tubules of a Larval Mayfly. Tissue \& Cell 15, 627637.

Nielsen, S., Smith, B.L., Christensen, E.I., Knepper, M.A., Agre, P., 1993. CHIP28 water channels are localized in constitutively waterpermeable segments of the nephron. J Cell Biol 120, 371-383.

Nishinakamura, R., Matsumoto, Y., Nakao, K., Nakamura, K., Sato, A., Copeland, N.G., Gilbert, D.J., Jenkins, N.A., Scully, S., Lacey, D.L., Katsuki, M., Asashima, M., Yokota, T., 2001. Murine homolog of SALL1 is essential for ureteric bud invasion in kidney development. Development 128, 3105-3115.

Nishinakamura, R., Sakaguchi, M., 2014. BMP signaling and its modifiers in kidney development. Pediatr Nephrol 29, 681-686.

Nocelli, R., Cintra-Socolowski, P., Roat, T., Silva-Zacarin, E., Malaspina, O., 2016. Comparative physiology of Malpighian tubules: form and function. Insect Physiol 2016, 13-23.

O'Brien, L.L., Grimaldi, M., Kostun, Z., Wingert, R.A., Selleck, R., Davidson, A.J., 2011. Wt1a, Foxc1a, and the Notch mediator Rbpj physically interact and regulate the formation of podocytes in zebrafish. Dev Biol 358, 318-330.

O'Connor, K.R., Beyenbach, K.W., 2001. Chloride channels in apical membrane patches of stellate cells of Malpighian tubules of Aedes aegypti. J Exp Biol 204, 367-378.

O'Donnell, M., 2010. Mechanisms of excretion and ion transport in invertebrates. Comprehensive Physiology, 1207-1289.

O'Donnell, M.J., Maddrell, S.H., 1995. Fluid reabsorption and ion transport by the lower Malpighian tubules of adult female Drosophila. J Exp Biol 198, 1647-1653.

O'Donnell, M.J., Rheault, M.R., Davies, S.A., Rosay, P., Harvey, B.J., Maddrell, S.H., Kaiser, K., Dow, J.A., 1998. Hormonally controlled chloride movement across Drosophila tubules is via ion channels in stellate cells. Am J Physiol 274, R1039-1049.

Pal, R., Kumar, K., 2012. Ultrastructural features of the larval Malpighian tubules of the flesh fly Sarcophaga ruficornis (Diptera: Sarcophagidae). International Journal of Tropical Insect Science 32, 166-172.

Pandey, R.N., Yaganti, S., Coffey, S., Frisbie, J., Alnajjar, K., Goldstein, D., 2010. Expression and immunolocalization of aquaporins HC-1, -2 , and -3 in Cope's gray treefrog, Hyla chrysoscelis. Comp Biochem Physiol A Mol Integr Physiol 157, 86-94.

Patari-Sampo, A., Ihalmo, P., Holthofer, H., 2006. Molecular basis of the glomerular filtration: nephrin and the emerging protein complex at the podocyte slit diaphragm. Ann Med 38, 483-492.

Paulus, H.F., 2000. Phylogeny of the Myriapoda - Crustacea - Insecta: a new attempt using photoreceptor structure. Journal of Zoological Systematics and Evolutionary Research 38, 189-208.

Perner, B., Englert, C., Bollig, F., 2007. The Wilms tumor genes wt1a and wt1b control different steps during formation of the zebrafish pronephros. Dev Biol 309, 87-96.

Peters, W., 1977. Possible Sites of Ultrafiltration in Tubifex tubifex Muller (Annelida, Oligochaeta). Cell Tissue Res 179, 367-375.

Pfeffer, P.L., Gerster, T., Lun, K., Brand, M., Busslinger, M., 1998. Characterization of three novel members of the zebrafish Pax2/5/8 family: dependency of Pax5 and Pax8 expression on the Pax2.1 (noi) function. Development 125, 3063-3074.

Piermarini, P.M., Grogan, L.F., Lau, K., Wang, L., Beyenbach, K.W., 2010. A SLC4-like anion exchanger from renal tubules of the mosquito (Aedes aegypti): evidence for a novel role of stellate cells in diuretic fluid secretion. Am J Physiol Regul Integr Comp Physiol 298, R642-660.

Preisig, P.A., Alpern, R.J., 1990. Pathways for apical and basolateral membrane NH3 and NH4+ movement in rat proximal tubule. Am J Physiol 259, F587-593.

Pullikuth, A.K., Aimanova, K., Kang'ethe, W., Sanders, H.R., Gill, S.S., 2006. Molecular characterization of sodium/proton exchanger 3 (NHE3) from the yellow fever vector, Aedes aegypti. J Exp Biol 209, 3529-3544.

Quaggin, S.E., Kreidberg, J.A., 2008. Development of the renal glomerulus: good neighbors and good fences. Development 135, 609-620. Quijada-Rodriguez, A.R., Treberg, J.R., Weihrauch, D., 2015. Mechanism of ammonia excretion in the freshwater leech Nephelopsis obscura: characterization of a primitive Rh protein and effects of high environmental ammonia. Am J Physiol Regul Integr Comp Physiol 309, R692-705.

Raciti, D., Reggiani, L., Geffers, L., Jiang, Q., Bacchion, F., Subrizi, A.E., Clements, D., Tindal, C., Davidson, D.R., Kaissling, B., Brandli, A.W., 2008. Organization of the pronephric kidney revealed by large-scale gene expression mapping. Genome Biol 9 , R84.

Randsø, P.V., Yamasaki, H., Bownes, S.J., Herranz, M., Di Domenico, M., Qii, G.B., Sørensen, M.V., 2019. Phylogeny of the Echinoderes coulli-group (Kinorhyncha: Cyclorhagida: Echinoderidae)-a cosmopolitan species group trapped in the intertidal. Invertebrate Systematics 33, 501-517.

Rheault, M.R., Okech, B.A., Keen, S.B., Miller, M.M., Meleshkevitch, E.A., Linser, P.J., Boudko, D.Y., Harvey, W.R., 2007. Molecular cloning, phylogeny and localization of AgNHA1: the first $\mathrm{Na}+/ \mathrm{H}+$ antiporter (NHA) from a metazoan, Anopheles gambiae. J Exp Biol 210, 3848-3861. Riemann, O., Ahlrichs, W.H., 2010. The evolution of the protonephridial terminal organ across Rotifera with particular emphasis on Dicranophorus forcipatus, Encentrum mucronatum and Erignatha clastopis (Rotifera: Dicranophoridae). Acta Zoologica (Copenhagen) 91, 199-211.

Rivest, B.R., 1992. Studies on the Structure and Function of the Larval Kidney Complex of Prosobranch Gastropods. The Biological Bulletin $182,305-323$.

Rohde, K., 1991. The evolution of protonephridia of the Platyhelminthes. Hydrobiologia 227, 315-321. 
Rohde, K., Cannon, L.R., Watson, N., 1988. Ultrastructure of the protonephridia of Monocelis (Proseriata, Monocelididae). J Submicrosc Cytol Pathol 20, 425-435.

Rohde, K., Watson, N.A., 1993. Ultrastructure of the protonephridial system of regenerating Stenostomum sp. (Platyhelminthes, Catenulida). Zoomorphology (Berlin) 113, 61-67.

Ruppert, E.E., 1994. Evolutionary origin of the vertebrate nephron. American Zoologist 34, 542-553.

Ruppert, E.E., Smith, P.R., 1988. The Functional Organization of Filtration Nephridia. Biological Reviews of the Cambridge Philosophical Society 63, 231-258.

Ruthensteiner, B., Wanninger, A., Haszprunar, G., 2001. The protonephridial system of the tusk shell, Antalis entalis (Mollusca, Scaphopoda). Zoomorphology (Berlin) 121, 19-26.

Sajithlal, G., Zou, D., Silvius, D., Xu, P.X., 2005. Eya 1 acts as a critical regulator for specifying the metanephric mesenchyme. Dev Biol 284, 323-336.

Santos, C.R., Estevao, M.D., Fuentes, J., Cardoso, J.C., Fabra, M., Passos, A.L., Detmers, F.J., Deen, P.M., Cerda, J., Power, D.M., 2004. Isolation of a novel aquaglyceroporin from a marine teleost (Sparus auratus): function and tissue distribution. J Exp Biol 207, 1217-1227.

Saulnier, D.M., Ghanbari, H., Brandli, A.W., 2002. Essential function of Wnt-4 for tubulogenesis in the Xenopus pronephric kidney. Dev Biol 248, $13-28$.

Saxén, L., Saxén, L., 1987. Organogenesis of the Kidney. Cambridge University Press.

Schill, R.O., 2019. Water bears: the biology of tardigrades. Springer.

Schmidt-Nielsen, K., 1997. Animal physiology: adaptation and environment. Cambridge University Press.

Schmidt-Rhaesa, A., 2007. The evolution of organ systems. Oxford University Press.

Schwaha, T.F., Ostrovsky, A.N., Wanninger, A., 2020. Key novelties in the evolution of the aquatic colonial phylum Bryozoa: evidence from soft body morphology. Biological Reviews 95, 696-729.

Scimone, M.L., Srivastava, M., Bell, G.W., Reddien, P.W., 2011. A regulatory program for excretory system regeneration in planarians. Development 138, 4387-4398.

Sebe-Pedros, A., Burkhardt, P., Sanchez-Pons, N., Fairclough, S.R., Lang, B.F., King, N., Ruiz-Trillo, I., 2013. Insights into the origin of metazoan filopodia and microvilli. Mol Biol Evol 30, 2013-2023.

Seifert, G., Rosenberg, J., 1977. Die Ultrastruktur der Nephrozyten von Peripatoides leuckarti (Saenger 1869)(Onychophora, Peripatopsidae). Zoomorphologie 86, 169-181.

Seitz, K.-A., 1987. Excretory organs, Ecophysiology of spiders. Springer, pp. 239-248.

Shafer, M.E.R., 2019. Cross-Species Analysis of Single-Cell Transcriptomic Data. Front Cell Dev Biol 7, 175.

Shatrov, A.B., 1998. The ultrastructure and possible functions of nephrocytes in the trombiculid mite Hirsutiella zachvatkini (Acariformes: Trombiculidae). Experimental \& applied acarology 22, 1-16.

Shim, K., Blake, K.J., Jack, J., Krasnow, M.A., 2001. The Drosophila ribbon gene encodes a nuclear BTB domain protein that promotes epithelial migration and morphogenesis. Development 128, 4923-4933.

Si, L., Pan, L., Wang, H., Zhang, X., 2018. Identification of the role of Rh protein in ammonia excretion of the swimming crab Portunus trituberculatus. J Exp Biol 221.

Smith, R., 1970. Hypo-osmotic urine in Nereis diversicolor. Journal of Experimental Biology 53, 101-108.

Smith, R., 1984. The larval nephridia of the brackish-water polychaete, Nereis diversicolor. Journal of morphology 179, 273-289.

Smythe, A.B., Holovachov, O., Kocot, K.M., 2019. Improved phylogenomic sampling of free-living nematodes enhances resolution of higherlevel nematode phylogeny. BMC evolutionary biology 19, 121.

Sozen, M.A., Armstrong, J.D., Yang, M., Kaiser, K., Dow, J.A., 1997. Functional domains are specified to single-cell resolution in a Drosophila epithelium. Proc Natl Acad Sci U S A 94, 5207-5212.

Star, R.A., Kurtz, I., Mejia, R., Burg, M.B., Knepper, M.A., 1987. Disequilibrium pH and ammonia transport in isolated perfused cortical collecting ducts. Am J Physiol 253, F1232-1242.

Storch, V., Herrmann, K., 1978. Podocytes in Blood-Vessel Linings of Phoronis muelleri (Phoronida, Tentaculata). Cell Tissue Res 190, $553-$ 556.

Taylor, H.H., 1971a. Fine Structure of Type-2 Cells in Malpighian Tubules of Stick Insect, Carausius morosus. Zeitschrift Fur Zellforschung Und Mikroskopische Anatomie 122, 411-\&.

Taylor, H.H., 1971b. Water and Solute Transport by Malpighian Tubules of Stick Insect, Carausius morosus - Normal Ultrastructure of Type1 Cells. Zeitschrift Fur Zellforschung Und Mikroskopische Anatomie 118, 333.

Temereva, E.N., Malakhov, V.V., 2006. Development of excretory organs in Phoronopsis harmeri (Phoronida): From protonephridium to nephromixium. Zoologichesky Zhurnal 85, 915-924.

Tena, J.J., Neto, A., de la Calle-Mustienes, E., Bras-Pereira, C., Casares, F., Gomez-Skarmeta, J.L., 2007. Odd-skipped genes encode repressors that control kidney development. Dev Biol 301, 518-531.

Terris, J., Ecelbarger, C.A., Marples, D., Knepper, M.A., Nielsen, S., 1995. Distribution of aquaporin-4 water channel expression within rat kidney. Am J Physiol 269, F775-785.

Tetelin, S., Jones, E.A., 2010. Xenopus Wnt11b is identified as a potential pronephric inducer. Dev Dyn 239, 148-159.

Teuchert, G., 1973. Die Feinstruktur des Protonephridialsystems von Turbanella cornuta Remane, einem marinen Gastrotrich der Ordnung Macrodasyoidea. Zeitschrift für Zellforschung und Mikroskopische Anatomie 136, 277-289.

Thiel, D., Hugenschutt, M., Meyer, H., Paululat, A., Quijada-Rodriguez, A.R., Purschke, G., Weihrauch, D., 2017. Ammonia excretion in the marine polychaete Eurythoe complanata (Annelida). J Exp Biol 220, 425-436.

Thomsen, J., Himmerkus, N., Holland, N., Sartoris, F.J., Bleich, M., Tresguerres, M., 2016. Ammonia excretion in mytilid mussels is facilitated by ciliary beating. J Exp Biol 219, 2300-2310.

Todt, C., Wanninger, A., 2010. Of tests, trochs, shells, and spicules: development of the basal mollusk Wirenia argentea (Solenogastres) and its bearing on the evolution of trochozoan larval key features. Frontiers in Zoology 7, 1-17.

Tomar, R., Mudumana, S.P., Pathak, N., Hukriede, N.A., Drummond, I.A., 2014. osr1 is required for podocyte development downstream of wt1a. J Am Soc Nephrol 25, 2539-2545.

Torrie, L.S., Radford, J.C., Southall, T.D., Kean, L., Dinsmore, A.J., Davies, S.A., Dow, J.A., 2004. Resolution of the insect ouabain paradox. Proc Natl Acad Sci U S A 101, 13689-13693.

Trapnell, C., 2015. Defining cell types and states with single-cell genomics. Genome Res 25, 1491-1498.

Tryggvason, K., Wartiovaara, J., 2001. Molecular basis of glomerular permselectivity. Current Opinion in Nephrology and Hypertension 10, 543-549. 
Tsang, T.E., Shawlot, W., Kinder, S.J., Kobayashi, A., Kwan, K.M., Schughart, K., Kania, A., Jessell, T.M., Behringer, R.R., Tam, P.P., 2000. activity is required for intermediate mesoderm differentiation in the mouse embryo. Dev Biol 223, 77-90.

Tschopp, P., Tabin, C.J., 2017. Deep homology in the age of next-generation sequencing. Philos Trans R Soc Lond B Biol Sci 372.

Urban, A.E., Zhou, X., Ungos, J.M., Raible, D.W., Altmann, C.R., Vize, P.D., 2006. FGF is essential for both condensation and mesenchymalepithelial transition stages of pronephric kidney tubule development. Dev Biol 297, 103-117.

Van Campenhout, C., Nichane, M., Antoniou, A., Pendeville, H., Bronchain, O.J., Marine, J.C., Mazabraud, A., Voz, M.L., Bellefroid, E.J., 2006. Evi1 is specifically expressed in the distal tubule and duct of the Xenopus pronephros and plays a role in its formation. Dev Biol 294 , 203-219.

Vandenbulcke, F., Grelle, C., Fabre, M.C., Descamps, M., 1998. Ultrastructural and autometallographic studies of the nephrocytes of Lithobius forficatus L.(Myriapoda, Chilopoda): role in detoxification of cadmium and lead. International Journal of Insect Morphology and Embryology 27, 111-120.

Vize, P.D., Seufert, D.W., Carroll, T.J., Wallingford, J.B., 1997. Model systems for the study of kidney development: Use of the pronephros in the analysis of organ induction and patterning. Developmental Biology 188, 189-204.

von Nordheim, H., Schrader, A., 1994. Ultrastructure and functional morphology of the protonephridia and segmental fenestrated lacunae in Protodrilus rubropharyngeus (Polychaeta, Protodrilidae). Helgoländer Meeresuntersuch ungen 48, 467-485.

Vu, H.T.K., Rink, J.C., McKinney, S.A., McClain, M., Lakshmanaperumal, N., Alexander, R., Alvarado, A.S., 2015. Stem cells and fluid flow drive cyst formation in an invertebrate excretory organ. Elife 4.

Waddell, A., 1968. The excretory system of the kidney worm Stephanurus dentatus (Nematoda). Parasitology 58, 907-919.

Wall, B.J., Oschman, J.L., Schmidt, B.A., 1975. Morphology and function of Malpighian tubules and associated structures in the cockroach, Periplaneta americana. Journal of morphology 146, 265-306.

Wall, S.M., 1996. Ammonium transport and the role of the Na, K-ATPase. Miner Electrolyte Metab 22, $311-317$.

Warner, F.D., 1969. Fine Structure of Protonephridia in Rotifer Asplanchna. Journal of Ultrastructure Research 29, 499-+.

Weavers, H., Prieto-Sanchez, S., Grawe, F., Garcia-Lopez, A., Artero, R., Wilsch-Brauninger, M., Ruiz-Gomez, M., Skaer, H., Denholm, B., 2009. The insect nephrocyte is a podocyte-like cell with a filtration slit diaphragm. Nature 457, 322-326.

Węglarska, B., 1980. Light and Electron-Microscopic Studies on the Excretory System of Macrobiotus richtersi Murray, 1911 (Eutardigrada). Cell Tissue Res 207, 171-182.

Weihrauch, D., 2006. Active ammonia absorption in the midgut of the Tobacco hornworm Manduca sexta L.: transport studies and mRNA expression analysis of a Rhesus-like ammonia transporter. Insect Biochem Mol Biol 36, 808-821.

Weihrauch, D., Chan, A.C., Meyer, H., Doring, C., Sourial, M., O'Donnell, M.J., 2012. Ammonia excretion in the freshwater planarian Schmidtea mediterranea. J Exp Biol 215, 3242-3253.

Weihrauch, D., Fehsenfeld, S., Quijada-Rodriguez, A., 2017. Nitrogen excretion in aquatic crustaceans, Acid-base balance and nitrogen excretion in invertebrates. Springer, pp. 1-24.

Weihrauch, D., O'Donnell, M., 2017. Acid-Base Balance and Nitrogen Excretion in Invertebrates. Cham: Springer International Publishing. doi 10, 978-973.

Wellik, D.M., Hawkes, P.J., Capecchi, M.R., 2002. Hox11 paralogous genes are essential for metanephric kidney induction. Genes Dev 16, 1423-1432.

Welsch, U., Rehkamper, G., 1987. Podocytes in the Axial Organ of Echinoderms. Journal of Zoology 213, 45-50.

Wenning, A., Cahill, M.A., Greisinger, U., Kaltenhauser, U., 1993. Organogenesis in the leech: development of nephridia, bladders and their innervation. Roux Arch Dev Biol 202, 329-340.

Werntz, H.O., 1963. Osmotic regulation in marine and fresh-water gammarids (Amphipoda). The Biological Bulletin 124, 225-239.

Westheide, W., 1985. Ultrastructure of the Protonephridia in the Dorvilleid Polychaete Apodotrocha progenerans (Annelida). Zoologica Scripta 14, 273-278.

White, J.T., Zhang, B., Cerqueira, D.M., Tran, U., Wessely, O., 2010. Notch signaling, wt1 and foxc2 are key regulators of the podocyte gene regulatory network in Xenopus. Development 137, 1863-1873.

Wigglesworth, V.B., 1943. The fate of haemoglobin in Rhodnius prolixus (Hemiptera) and other blood-sucking arthropods. Proceedings of the Royal Society of London. Series B-Biological Sciences 131, 313-339.

Wild, W., Pogge von Strandmann, E., Nastos, A., Senkel, S., Lingott-Frieg, A., Bulman, M., Bingham, C., Ellard, S., Hattersley, A.T., Ryffel, G.U., 2000. The mutated human gene encoding hepatocyte nuclear factor 1 beta inhibits kidney formation in developing Xenopus embryos. Proc Natl Acad Sci U S A 97, 4695-4700.

Wingert, R.A., Davidson, A.J., 2008. The zebrafish pronephros: a model to study nephron segmentation. Kidney Int $73,1120-1127$.

Wingert, R.A., Selleck, R., Yu, J., Song, H.D., Chen, Z., Song, A., Zhou, Y., Thisse, B., Thisse, C., McMahon, A.P., Davidson, A.J., 2007. The cdx genes and retinoic acid control the positioning and segmentation of the zebrafish pronephros. PLoS Genet 3, $1922-1938$.

Wolff, J., Merker, H.-J., 1966. Ultrastruktur und Bildung von Poren im Endothel von porösen und geschlossenen Kapillaren. Zeitschrift für Zellforschung und Mikroskopische Anatomie 73, 174-191.

Woodruff, J.B., Mitchell, B.J., Shankland, M., 2007. Hau-Pax3/7A is an early marker of leech mesoderm involved in segmental morphogenesis, nephridial development, and body cavity formation. Dev Biol 306, 824-837.

Xu, P.X., Zheng, W., Huang, L., Maire, P., Laclef, C., Silvius, D., 2003. Six1 is required for the early organogenesis of mammalian kidney. Development 130, 3085-3094.

Yasui, M., Kwon, T.H., Knepper, M.A., Nielsen, S., Agre, P., 1999. Aquaporin-6: An intracellular vesicle water channel protein in renal epithelia. Proc Natl Acad Sci U S A 96, 5808-5813.

Zhang, F., Zhao, Y., Chao, Y., Muir, K., Han, Z., 2013. Cubilin and amnionless mediate protein reabsorption in Drosophila nephrocytes. J Am Soc Nephrol 24, 209-216.

Zhuang, S., Shao, H., Guo, F., Trimble, R., Pearce, E., Abmayr, S.M., 2009. Sns and Kirre, the Drosophila orthologs of Nephrin and Neph1, direct adhesion, fusion and formation of a slit diaphragm-like structure in insect nephrocytes. Development 136, $2335-2344$.

Ziegler, A., Faber, C., Bartolomaeus, T., 2009. Comparative morphology of the axial complex and interdependence of internal organ systems in sea urchins (Echinodermata: Echinoidea). Frontiers in Zoology 6. 